\title{
Influence of meteorological variability on interannual variations of springtime boundary layer ozone over Japan during 1981-2005
}

\author{
J. Kurokawa ${ }^{1}$, T. Ohara ${ }^{1}$, I. Uno ${ }^{2}$, M. Hayasaki ${ }^{3}$, and H. Tanimoto ${ }^{1}$ \\ ${ }^{1}$ National Institute for Environmental Studies, Onogawa, Tsukuba, Ibaraki, Japan \\ ${ }^{2}$ Research Institute for Applied Mechanics, Kyushu University, Kasuga, Fukuoka, Japan \\ ${ }^{3}$ Center for Environmental Remote Sensing, Chiba University, Yayoi, Inage, Chiba, Japan
}

Received: 21 February 2009 - Published in Atmos. Chem. Phys. Discuss.: 23 March 2009

Revised: 10 August 2009 - Accepted: 13 August 2009 - Published: 1 September 2009

\begin{abstract}
We investigated the influence of meteorological variability on the interannual variation of springtime boundary layer ozone over Japan during 1981-2005 by multiyear simulations with the Models-3 Community Multiscale Air Quality (CMAQ) modeling system and the Regional Emission Inventory in Asia (REAS). CMAQ/REAS generally reproduced the observed interannual variability of springtime ozone over Japan, showing year-to-year variations larger than the annual rate of increase of the long-term trend. We then analyzed the influence of the interannual variation of meteorology in simulated results by using the fixed emissions for 2000 and meteorological fields for each year. As a reference parameter, we calculated the area-weighted surface pressure anomaly over the Pacific Ocean east of Japan. When the anomaly has a large negative value, polluted air masses from continental Asia tend to be transported directly to Japan by westerly winds. In contrast, when the anomaly has a large positive value, influence of the outflow from continental Asia tends to be small because the westerly components of wind fields around Japan are comparatively weak. Instead, southerly winds are relatively strong and transport clean air masses from the Pacific Ocean to Japan. Consequently, springtime ozone over Japan is higher (lower) than in ordinary years when the anomaly has a large negative (positive) value. In general, the interannual variation of springtime ozone over Japan is sensitive to the outflow from continental Asia. We also found some correlation between springtime ozone over Japan and the El Niño-Southern Oscillation, indicating that higher and lower springtime ozone over Japan are related to La Niña and El Niño, respectively.
\end{abstract}

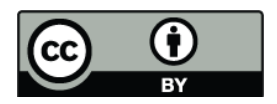

Correspondence to: J. Kurokawa (kurokawa.junichi@nies.go.jp)
Differences in the meridional displacement and diversity of cyclone tracks near Japan between El Niño and La Niña years may be responsible for interannual variations in the springtime boundary layer ozone over Japan.

\section{Introduction}

Tropospheric ozone $\left(\mathrm{O}_{3}\right)$ is a key species in atmospheric chemistry. $\mathrm{O}_{3}$ and its photochemical derivative $\mathrm{OH}$ are major oxidants of most natural and anthropogenic compounds and play controlling roles in the oxidation capacity of the atmosphere. In addition, tropospheric $\mathrm{O}_{3}$ influences the Earth's climate as a greenhouse gas (Intergovernmental Panel on Climate Change, 2007), and negatively affects human health, agricultural crops, and natural vegetation (Wang and Mauzerall, 2004; Mauzerall et al., 2005). Therefore, understanding the spatial distribution, long-term trends, and interannual variation (IAV) of tropospheric $\mathrm{O}_{3}$ is very important.

In Japan, surface and boundary layer (BL) $\mathrm{O}_{3}$ has increased continuously since the 1980 s despite reductions in the concentrations of nitrogen oxides $\left(\mathrm{NO}_{\mathrm{x}}=\mathrm{NO}+\mathrm{NO}_{2}\right)$ and non-methane volatile organic compounds (NMVOC), which are precursors of $\mathrm{O}_{3}$ (Ohara et al., 2008). Many studies have reported that trans-boundary transport of $\mathrm{O}_{3}$ and its precursors, especially from East Asia, has greatly influenced the recent increase of $\mathrm{O}_{3}$ over Japan (Pochanart et al., 1999; Naja and Akimoto, 2004; Tanimoto et al., 2005; Tanimoto, 2009; Yamaji et al., 2006, 2008). Tanimoto et al. (2005) estimated that the regional build-up of $\mathrm{O}_{3}$ due to anthropogenic emissions in eastern China and Korea accounts for about $10 \mathrm{ppbv}$ in March and April and about 20 ppbv in May over Japan. Ohara et al. (2007) reported that emissions of $\mathrm{O}_{3}$ precursors

Published by Copernicus Publications on behalf of the European Geosciences Union. 
Table 1. Abbreviations used in the text.

\begin{tabular}{|c|c|}
\hline Abbreviation & Definition \\
\hline ASPA & Area-weighted surface pressure anomaly (see Sect. 3.4) \\
\hline $\mathrm{BL}$ & Boundary layer \\
\hline CEC & Central eastern China (see Fig. 1) \\
\hline $\mathrm{E}_{y y} \mathrm{M}_{y y}$ & $\begin{array}{l}\text { The simulation using emission data sets and meteorological fields for } \\
\text { each year }\end{array}$ \\
\hline $\mathrm{E}_{00} \mathrm{M}_{y y}$ & $\begin{array}{l}\text { The simulation using the fixed emissions for } 2000 \text { and meteorological } \\
\text { fields for each year }\end{array}$ \\
\hline $\mathrm{FA}_{\mathrm{SC}}$ & Flux anomalies of springtime $\mathrm{BL}_{3}$ along $\mathrm{L}_{\mathrm{SC}}$ \\
\hline $\mathrm{FA}_{\mathrm{SJ}}$ & Flux anomalies of springtime $\mathrm{BL} \mathrm{O}_{3}$ along $\mathrm{L}_{\mathrm{SJ}}$ \\
\hline FAwJ & Flux anomalies of springtime $\mathrm{BL} \mathrm{O}_{3}$ along $\mathrm{L}_{\mathrm{WJ}}$ \\
\hline IAV & Interannual variation \\
\hline $\mathrm{L}_{\mathrm{SC}}$ & Southern boundary of CEC (see Fig. 1) \\
\hline $\mathrm{L}_{\mathrm{SJ}}$ & Southern boundary of WCJ (see Fig. 1) \\
\hline LWJ & Western boundary of WCJ (see Fig. 1) \\
\hline NINO3 & The Niño3 index \\
\hline WCJ & Western and central Japan (see Fig. 1) \\
\hline
\end{tabular}

in Asia, particularly in China, have been growing rapidly during the past two decades. Thus, it is probable that the impacts of trans-boundary pollution are becoming correspondingly larger.

Although $\mathrm{O}_{3}$ concentrations over Japan show a long-term increasing trend, they also show large year-to-year variations (Ohara et al., 2008). The main factors causing these variations are the $\mathrm{IAV}$ of $\mathrm{O}_{3}$ precursor emissions, biomass burning, stratospheric $\mathrm{O}_{3}$, and meteorology. Although anthropogenic emissions from Japan and other Asian countries such as China and Korea have a large impact on the $\mathrm{O}_{3}$ concentration over Japan, we have been unable to identify year-toyear variations (in contrast to a long-term trend) in these anthropogenic emissions similar to those in $\mathrm{O}_{3}$ concentrations over Japan (Ohara et al., 2007, 2008). Several studies have reported that the IAV of wildfire emissions and of the $\mathrm{O}_{3}$ produced by them is an important factor affecting the IAV of tropospheric $\mathrm{O}_{3}$ (Doherty et al., 2006; Koumoutsaris et al., 2008). Recently, the influences of lower stratospheric $\mathrm{O}_{3}$ and stratosphere-troposphere exchange on the IAV of tropospheric $\mathrm{O}_{3}$ have been analyzed (Ordóñez et al., 2007; Koumoutsaris et al., 2008; Terao et al., 2008). Terao et al. (2008) indicated that in the northern extratropics such as over Canada and Europe, tropospheric $\mathrm{O}_{3}$ is highly influenced by $\mathrm{O}_{3}$ in the lower stratosphere but that stratospheric influences are small in other regions, especially those influenced by large export events from East Asia. With respect to meteorology, several studies have reported the influence of IAV of continental-Asian outflow on tropospheric $\mathrm{O}_{3}$ and its relations to El Niño-Southern Oscillation (ENSO) (Liu et al., 2003; Liu et al., 2005; Koumoutsaris et al., 2008). However, influence of meteorology on the IAV of $\mathrm{O}_{3}$ over the northwestern Pacific region, including Japan, where the impacts of continental-Asian outflow are significantly high, has not been studied.
The purpose of this study is to investigate the effects of meteorological variability on the IAV of $\mathrm{O}_{3}$ over Japan. It is expected that the concentration of pollutants within air masses exported from continental Asia will continue to increase and these air masses are known to have their greatest effect on the springtime BL. Trans-boundary $\mathrm{O}_{3}$ seems to have a large impact on the maximum $\mathrm{O}_{3}$ concentration and exceedances of air quality standards in Japan, especially in the springtime (Akimoto, 2003; Zhang et al., 2004; Tanimoto et al., 2005; Tanimoto, 2009; Yamaji et al., 2006, 2008). Thus, we focused on the influences of the IAV of continentalAsian outflow on the springtime $\mathrm{BL} \mathrm{O}_{3}$ over Japan. In this study, we did not focus on the effects of year-to-year variations in biomass burning emissions. We conducted two sets of multiyear springtime simulations for 1981-2005 using the Models-3 Community Multiscale Air Quality (CMAQ) modeling system (Byun and Schere, 2006) and the Regional Emission Inventory in Asia (REAS) (Ohara et al., 2007). Here, we evaluate the general model performance for $\mathrm{O}_{3}$ over East Asia and the reproducibility of the observed IAV of $\mathrm{O}_{3}$ over Japan by simulated results using emission data sets and meteorological fields for each year. Then, we examine the influences of the IAV of the meteorology and the processes causing the relatively higher and lower springtime BL $\mathrm{O}_{3}$ over Japan by simulated results using fixed emissions for 2000. Finally, we discuss the relationships between ENSO events and the IAV of $\mathrm{O}_{3}$ over Japan. We define several abbreviations in this paper, and provide a list of them in Table 1 for the reader's convenience. 


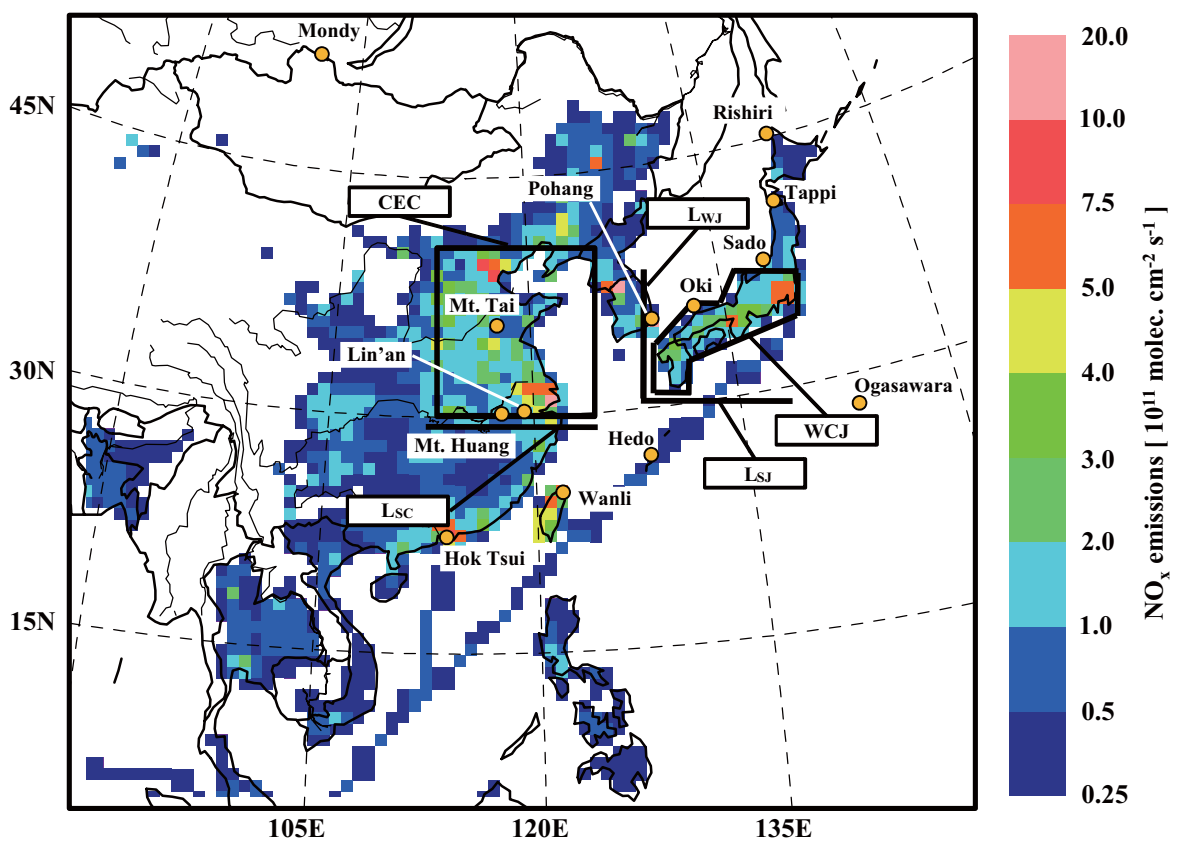

Fig. 1. Model domain of CMAQ showing the horizontal distribution of REAS $\mathrm{NO}_{\mathrm{x}}$ emissions for 2000. The box labeled WCJ denotes western and central Japan, the focal area of our analysis of the IAV of springtime $\mathrm{BL} \mathrm{O}_{3}$. The lines $\mathrm{L}_{\mathrm{WJ}}$ and $\mathrm{L}_{\mathrm{SJ}}$ are respectively defined as the western and southern boundaries of WCJ, along which we calculated the $\mathrm{BL} \mathrm{O}_{3}$ fluxes. The box labeled CEC denotes central eastern China, and line $\mathrm{L}_{\mathrm{SC}}$ is defined as the southern boundary of CEC for the calculation of $\mathrm{BL} \mathrm{O}_{3}$ fluxes. The locations of $\mathrm{O}_{3}$ monitoring sites used for model validation in Sect. 3.1 are also shown as orange circles.

\section{Model description}

\subsection{Chemical transport model}

The three-dimensional regional-scale chemical transport model used in this work was developed jointly by Kyushu University and the National Institute for Environmental Studies (NIES) (Uno et al., 2005), based on the Models-3 CMAQ version 4.4 modeling system released by the US Environmental Protection Agency (Byun and Schere, 2006). This model is driven by meteorological fields generated by the Regional Atmospheric Modeling System (RAMS) version 4.4 (Pielke et al., 1992). The horizontal model domain for the CMAQ simulation is $6240 \times 5440 \mathrm{~km}^{2}$ on a rotated polar stereographic map projection centered at $25^{\circ} \mathrm{N}, 115^{\circ} \mathrm{E}$, with a grid resolution of $80 \times 80 \mathrm{~km}^{2}$ (Fig. 1). For vertical resolution, we used 14 layers up to $23 \mathrm{~km}$ in the sigma-z coordinate system. In this study, we defined the BL as from the surface to an altitude of $1 \mathrm{~km}$; the BL comprises 5 layers in the model coordinate system. We adopted the Statewide Air Pollution Research Center (SAPRC)-99 scheme (Carter, 2000) for gasphase chemistry (with 72 chemical species and 214 chemical reactions, including 30 photochemical reactions). For aerosol calculations, we applied the third-generation CMAQ aerosol module (AERO3), which includes the Secondary Organic Aerosols Model (SORGAM) (Schell et al., 2001) as a secondary organic aerosol model, ISORROPIA (Nenes et al., 1998) as an inorganic aerosol model, and the piecewise parabolic method (PPM) (Binkowski and Shankar, 1995) as the regional particulate model. Note that both the gas-phase chemistry and aerosol schemes are applicable only to the tropospheric atmosphere. Schemes applicable to the stratosphere are not used in the model.

\subsection{Outline and setting of the numerical experiments}

We conducted two sets of numerical experiments. First, we performed a 25-year springtime simulation for 1981-2005 using emission data sets and meteorological fields for each year (called " $\mathrm{E}_{y y} \mathrm{M}_{y y}$ "). Second, we conducted a simulation for the same period using the fixed emissions for 2000 and the meteorological fields for each year (called " $\mathrm{E}_{00} \mathrm{M}_{y y}$ "). We performed simulations for the period from 1 January to 31 May of each year. In this study, we defined springtime as April and May, and thus treated the first 3 months as the spin-up period. The purpose of $\mathrm{E}_{y y} \mathrm{M}_{y y}$ was to evaluate the ability of the model to reproduce the observed results. In this work, we focused on the influence of meteorological variability on the IAV of springtime $\mathrm{BL} \mathrm{O}_{3}$ over Japan. Therefore, the simulated $\mathrm{E}_{00} \mathrm{M}_{y y}$ results, which elucidate the sensitivity of springtime $\mathrm{BL} \mathrm{O}_{3}$ over Japan to meteorological factors, are mainly used in the following analysis. 


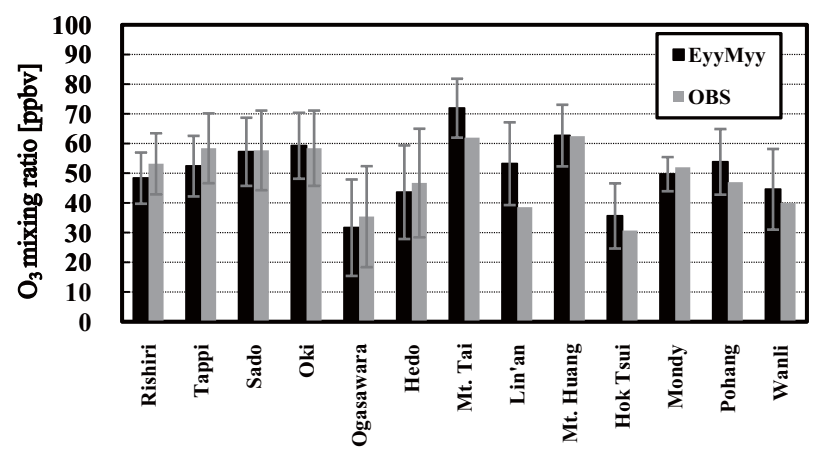

Fig. 2. Comparison of the springtime averaged $\mathrm{O}_{3}$ mixing ratios between observations (gray bars) and model simulations by $\mathrm{E}_{y y} \mathrm{M}_{y y}$ (black bars). Locations and general information on monitoring sites are presented in Fig. 1 and Table 2, respectively. Data from all periods shown in Table 2 were included in the calculation of the springtime average and standard deviation at each site. The whiskers indicate 1 standard deviation for both observation and simulation. Several observations without whiskers were taken from published research papers.

Both experiments used the same meteorological fields and initial and boundary conditions for chemical tracers. Meteorological fields for each year were generated by RAMS with initial and boundary conditions defined by the National Centers for Environmental Prediction/National Center for Atmospheric Research (NCEP/NCAR) Reanalysis 1 data sets (http://www.cdc.noaa.gov/cdc/data.ncep.reanalysis. html) (Kalnay et al., 1996; Kistler et al., 2001). The reanalysis data sets have a spatial resolution of $2.5^{\circ} \times 2.5^{\circ}$ and a temporal resolution of 6 hours. The meteorological parameters, such as temperature, wind speed and direction, relative humidity, and precipitation, simulated by this system have been validated by Yoshida et al. (2006) and Uno et al. (2003, 2005). The initial fields of chemical compounds were prepared by the initial conditions processor (ICON) of the CMAQ modeling system (Byun and Schere, 2006). The influence of the initial condition was eliminated during the spin-up period (3 months). The monthly averaged lateral boundary conditions for most chemical tracers were obtained from the global chemical transport model CHASER (Chemical AGCM for Study of Atmospheric Environment and Radiative Forcing; Sudo et al., 2002). In this study, we did not examine the influences of the IAV of inflow from outside of Asia. Thus, we assumed no IAV as the lateral boundary condition. With respect to the upper boundary condition, we did not explicitly incorporate the $\mathrm{O}_{3}$ inflow across the tropopause from CHASER. In the model domain, intrusions of $\mathrm{O}_{3}$ from the upper layers across the lateral boundaries determine the stratospheric and upper tropospheric $\mathrm{O}_{3}$ concentrations. As mentioned in Sect. 1, the influence of inflow from the stratosphere on the IAV of $\mathrm{BL} \mathrm{O}_{3}$ over Japan seems to be relatively small. Therefore, the IAV of stratospheric $\mathrm{O}_{3}$ was not considered in this study.
$\mathrm{E}_{y y} \mathrm{M}_{y y}$ requires the emission inventories for 1981-2005, and $\mathrm{E}_{00} \mathrm{M}_{y y}$ needs only the data set from 2000. We prepared data sets for anthropogenic emissions of sulfur dioxide $\left(\mathrm{SO}_{2}\right), \mathrm{NO}_{\mathrm{x}}$, carbon monoxide $(\mathrm{CO}), \mathrm{NMVOC}$, black carbon, organic carbon, and ammonia $\left(\mathrm{NH}_{3}\right)$ using REAS version 1.1 (Ohara et al., 2007, http://www.jamstec.go.jp/fregc/ research/p3/emission.htm). REAS data sets for 1981-2003 include most anthropogenic sources such as fuel combustion and industrial processes. We extended the data sets until 2005 using the same methodology as Ohara et al. (2007) and with new statistics such as energy consumption and industrial activities (e.g. International Energy Agency, 2006; United Nations, 2005, 2006). We took parameters such as emission factors and removal efficiencies from those for the year 2003. Springtime emission is exactly the same as annual average flux in this study, because seasonal variation is not considered in the REAS database. According to Streets et al. (2003), springtime fractions of annual emissions in China are similar to the annual mean values. We took biogenic emissions of isoprene and monoterpenes from monthly estimations for the 1990s by Guenther et al. (1995). We did not include $\mathrm{NO}_{\mathrm{x}}$ emissions from soil or lightning in the model. With respect to biomass burning emissions, Tanimoto et al. (2008) reported the impact of boreal biomass burning on $\mathrm{O}_{3}$ at Rishiri, the northern island of Japan, in 1998, 2002, and 2003. According to their study, two episodes observed in 2002 and 2003 suggested that at Rishiri, $\mathrm{O}_{3}$ in wildfirepolluted plumes was comparable to the magnitude typically observed in industrially-polluted air masses from the Asian continent. However, our focus was not on the effects of yearto-year changes in wildfire emissions, and, in Asia, their recent long-term increasing trend is smaller than that of anthropogenic emissions. Thus, we used climatological inventories for the late 1990s from Streets et al. (2003) in this work. The IAV of $\mathrm{O}_{3}$ over Japan might be affected by the IAV of wildfire emissions. We plan to examine the relative influence of biomass burning in a future study.

\section{Results and discussion}

\subsection{Validation of simulated $\mathrm{O}_{3}$ over East Asia by observations}

The modeling system described in Sect. 2 has previously been used for analyzing tropospheric $\mathrm{O}_{3}$ over East Asia, including Japan (see Uno et al., 2005; Tanimoto et al., 2005; Yamaji et al., 2006, 2008; He et al., 2008), and, in these studies, the simulated results showed good agreement with observations. In this section, we further evaluate the general performance of our modeling system for springtime $\mathrm{O}_{3}$ over East Asia.

Figure 2 compares the springtime averaged $\mathrm{O}_{3}$ simulated by $\mathrm{E}_{y y} \mathrm{M}_{y y}$ (black bars) with observations (gray bars), taken at Japanese remote monitoring sites of the Acid Deposition 
Table 2. General information of $\mathrm{O}_{3}$ monitoring sites used for model evaluation in Sect. 3.1.

\begin{tabular}{lccrrll}
\hline $\begin{array}{l}\text { Monitoring } \\
\text { Sites }\end{array}$ & $\begin{array}{c}\text { North } \\
\text { Latitude }\end{array}$ & $\begin{array}{c}\text { East } \\
\text { Longitude }\end{array}$ & $\begin{array}{r}\text { Elevation } \\
{[\mathrm{m}]}\end{array}$ & Periods & $\begin{array}{l}\text { Site } \\
\text { Characteristics }\end{array}$ & Data Sources \\
\hline Rishiri & 45.12 & 141.20 & 40 & $1998-2005$ & Remote & EANET \\
Tappi & 41.25 & 140.35 & 105 & $1999-2005$ & Remote & EANET \\
Sado & 38.23 & 138.40 & 136 & $1998-2005$ & Remote & EANET \\
Oki & 36.28 & 133.18 & 90 & $1998-2005$ & Remote & EANET \\
Ogasawara & 27.08 & 142.22 & 230 & $1998-2005$ & Remote & EANET \\
Hedo & 26.87 & 128.25 & 60 & $1999-2005$ & Remote & EANET \\
Mt. Tai & 36.25 & 117.10 & 1533 & $2004-2005$ & Mountain & Li et al. (2007) \\
Lin'an & 30.30 & 119.73 & 132 & $1999-2001$ & Rural & Lin et al. (2009) \\
Mt. Huang & 30.13 & 118.15 & 1836 & $2004-2005$ & Mountain & Li et al. (2007) \\
Hok Tsui & 22.22 & 114.25 & 60 & $1994-1996$ & Remote & WDCGG \\
Mondy & 51.67 & 101.00 & 2000 & $2001-2007$ & Remote & Lin et al. (2009) \\
Pohang & 36.00 & 129.00 & - & $1995-2000$ & Remote & Kim et al. (2006) \\
Wanli & 25.18 & 121.68 & - & $1994-2005$ & Remote & Chou et al. (2006) \\
\hline
\end{tabular}

Monitoring Network in East Asia (EANET), at the Hok Tsui site of the World Data Centre for Greenhouse Gases (WDCGG), and from several measurements mainly at remote sites reported in published research papers (see Table 2 for references). Locations and general information on these monitoring sites are presented in Fig. 1 and Table 2, respectively. Data from all periods shown in Table 2 are included in the calculation of the springtime average at each site. In general, the simulated results reproduced well the observed springtime averaged $\mathrm{O}_{3}$ over Japan (Rishiri, Tappi, Sado, and Oki), the western Pacific (Ogasawara and Hedo), and continental Asia (Mt. Tai, Lin'an, Mt. Huang, Hok Tsui, Mondy, Pohang, and Wanli). Modeled $\mathrm{O}_{3}$ at Lin' an overestimated the observations by about 15 ppbv. Lin' an is in a rural area but is likely affected by polluted air masses from the industrialized Yangtze Delta region. One possible reason for the discrepancy in the Lin'an results is the underestimation of $\mathrm{NO}_{\mathrm{x}}$ titration of $\mathrm{O}_{3}$ because of the relatively coarse horizontal and vertical resolution of the model grid. Similar features are found at the urban, suburban, and rural monitoring stations over Japan and are discussed in Sect. 3.3 in detail. At other monitoring sites over continental Asia, observed surface $\mathrm{O}_{3}$ were well reproduced by modeled results. Figure 3 compares the hourly mean $\mathrm{O}_{3}$ mixing ratios between the observation and model simulation results at four Japanese remote sites (Sado, Oki, Ogasawara, and Hedo) in scatter plots. Hourly averaged data during springtime of all periods shown in Table 2 are plotted at three-hour intervals. At each monitoring site, model simulations generally reproduced the hourly $\mathrm{O}_{3}$ mixing ratios well. The correlation coefficients between simulated and observed results ranged from about 0.51 to 0.65 . No systematic underestimation or overestimation was found at all monitoring sites. Thus, although there are several discrepancies between simulated and observed results, our modeling system generally reproduced the observations and was validated for the analysis of springtime $\mathrm{O}_{3}$ over East Asia.

\subsection{The climatological springtime $\mathrm{BL} \mathrm{O}_{3}$ over East Asia}

This section describes the general features of the modeled climatological springtime $\mathrm{BL} \mathrm{O}_{3}$ over East Asia (25-year average during 1981-2005). In this study, we defined the simulated springtime $\mathrm{BL} \mathrm{O}_{3}$ as the $\mathrm{O}_{3}$ concentration averaged over the lower 5 layers of the model (from the surface to $1 \mathrm{~km}$ of altitude) during April and May. Data from all times of day are included in the springtime average. The spatial distribution of the climatological $\mathrm{BL} \mathrm{O}_{3}$, simulated by $\mathrm{E}_{y y} \mathrm{M}_{y y}$, is shown in Fig. 4a, overlaid with the climatological springtime wind fields in the $\mathrm{BL}$. High $\mathrm{O}_{3}$ of more than $55 \mathrm{ppbv}$ is widespread over central eastern China (CEC; Fig. 1), the Korean peninsula, and Japan. The mean wind fields in the high $\mathrm{O}_{3}$ area are westerly and southwesterly, suggesting that polluted air masses of continental Asia are likely to be transported to Japan. $\mathrm{O}_{3}$ mixing ratios over the Pacific Ocean south of Japan are generally low.

Figure $4 \mathrm{~b}$ shows the spatial distribution of the climatological springtime $\mathrm{BL} \mathrm{O}_{3}$, as in Fig. 4a, but simulated by $\mathrm{E}_{00} \mathrm{M}_{y y}$, along with the standard deviation of the $\mathrm{O}_{3}$ mixing ratios at each grid cell (contours) calculated from the simulated results by $\mathrm{E}_{00} \mathrm{M}_{y y}$ for each year and the climatological fields. Although the mixing ratios of $\mathrm{O}_{3}$ simulated by $\mathrm{E}_{00} \mathrm{M}_{y y}$ (Fig. 4b) are slightly higher than those simulated by $\mathrm{E}_{y y} \mathrm{M}_{y y}$ (Fig. 4a), their spatial distributions are very similar. The standard deviation maxima are south of Japan, where the climatological $\mathrm{O}_{3}$ gradient is largest; thus, the sensitivity to the IAV of $\mathrm{O}_{3}$ can be considered to be high. Over the Japanese Islands, $\mathrm{O}_{3}$ variability is largest over western and central Japan (WCJ; defined in Fig. 1), especially in the western part of this region, where the influence of $\mathrm{O}_{3}$ from continental Asia is expected to be large. In contrast, the IAV of $\mathrm{O}_{3}$ is relatively small in northern Japan. Therefore, in the following sections, we analyze mainly the IAV of the springtime $\mathrm{O}_{3}$ over WCJ. 
6292 J. Kurokawa et al.: Meteorological variability on interannual variations of springtime boundary layer ozone over Japan
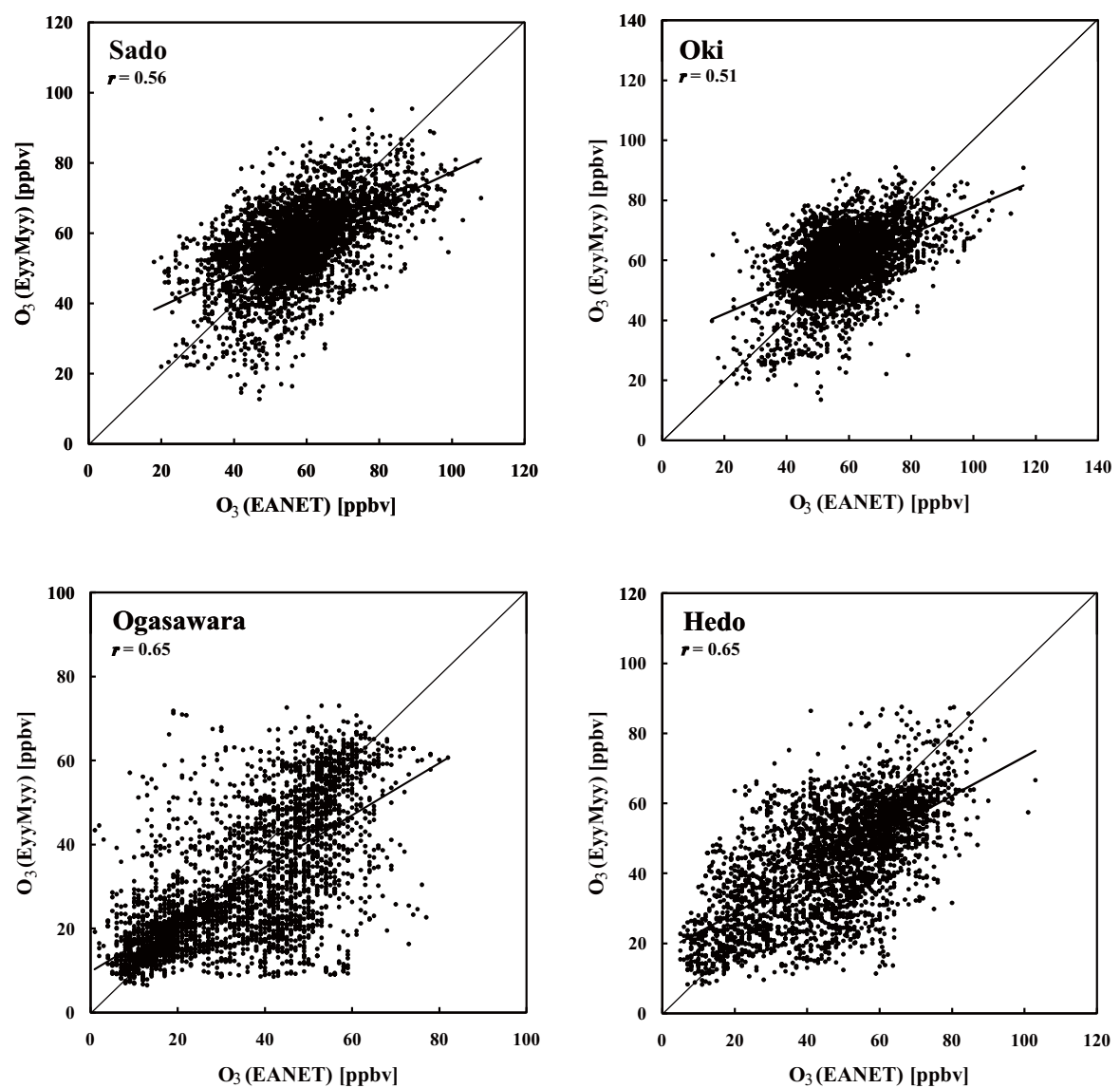

Fig. 3. Comparison of observed and simulated hourly mean $\mathrm{O}_{3}$ mixing ratios at four Japanese remote sites (Sado, Oki, Ogasawara, and Hedo). Hourly averaged data during springtime of all periods shown in Table 2 are plotted at three-hour intervals. The linear regression lines of hourly averaged $\mathrm{O}_{3}$ values between the observations and simulations are also shown. The $\mathrm{E}_{y y} \mathrm{M}_{y y}$ scenario was used for the model simulation.

(a) Climatological $\mathrm{O}_{3}\left(E_{y y} M_{y y}\right)$ and wind fields

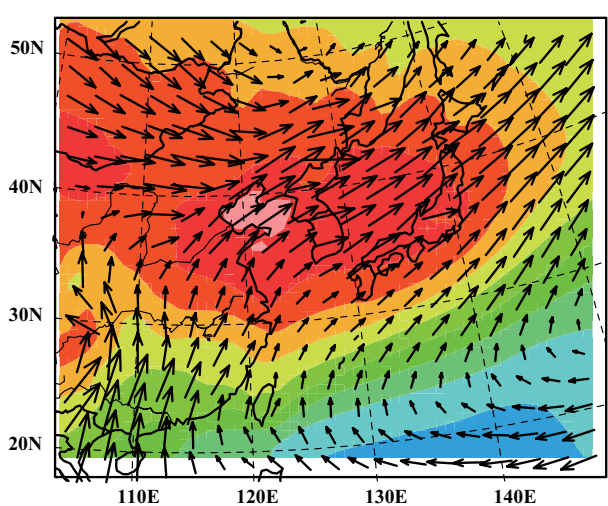

(b) Climatological $\mathrm{O}_{3}\left(\mathrm{E}_{00} \mathrm{M}_{\mathrm{yy}}\right)$ and standard deviations

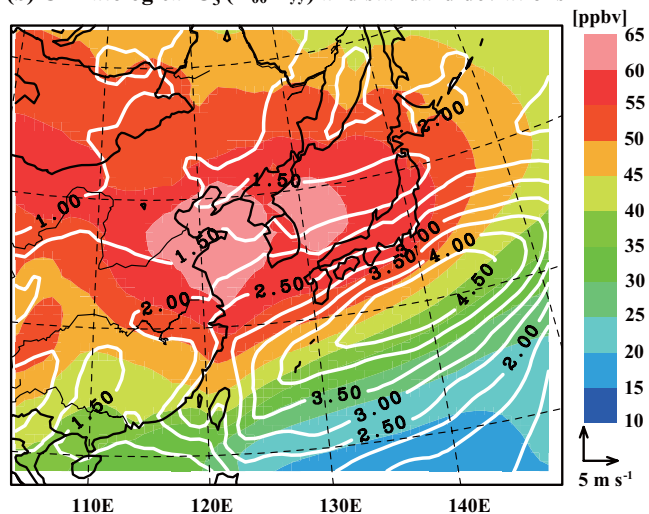

Fig. 4. (a) Spatial distributions of simulated springtime $\mathrm{BL} \mathrm{O}_{3}$ averaged over 1981-2005 for the $\mathrm{E}_{y y} \mathrm{M}_{y y}$ scenario, overlaid with the springtime climatological wind field in the BL. (b) The same as in (a) for the $\mathrm{E}_{00} \mathrm{M}_{y y}$ scenario, overlaid with the standard deviations of $\mathrm{O}_{3}$ mixing ratios, calculated at each grid point using the simulated fields for each year and the 25-year average. 


\subsection{The interannual variation of springtime $\mathrm{O}_{3}$ over western and central Japan}

\subsubsection{Observation data}

In Japan, continuous measurements of general air pollution at ground level are conducted at air quality monitoring stations all around the country. The stations are managed and operated by the Ministry of the Environment of Japan and by local governments. At these stations, the concentrations of photochemical oxidants $\left(\mathrm{O}_{\mathrm{x}}\right)$ are observed by absorption spectrophotometry using a neutral potassium iodide solution (KI method), or by photometric instruments based on absorption in the ultraviolet region (UV method) (Ministry of the Environment of Japan, 2007). $\mathrm{O}_{\mathrm{x}}$ observed at the stations is defined as oxidizing substances produced by photochemical reactions and only those capable of isolating iodine from neutral potassium iodide (such as $\mathrm{O}_{3}$, peroxyacetyl nitrate, and peroxypropionyl nitrate), excluding $\mathrm{NO}_{\mathrm{x}}$. The majority (about $60 \%$ for the year of 2006) of $\mathrm{O}_{\mathrm{x}}$ measurements are calibrated by the KI method at each station. However, variability of $\mathrm{O}_{\mathrm{x}}$ concentrations obtained from the KI method seems to be larger than that by the UV method. Recently, Mukai et al. (2007) has reported the results of experiments in which measurements of $\mathrm{O}_{\mathrm{x}}$ standards by 25 local government instruments were compared with measurements performed with a Standard Reference Photometer (SRP) \#35, built by the US National Institute of Standard and Technology (NIST) and maintained by the Japanese National Institute for Environmental Studies (NIES) (Tanimoto et al., 2006). According to this report, the variability (one standard deviation) of the KI and UV methods was about $5.6 \%$ and $1.1 \%$, respectively. Also the KI and UV methods respectively yielded $\mathrm{O}_{3}$ concentrations about 9\% and 5\% larger than those obtained by SPR \#35. Despite these differences between the KI and UV methods, there are no other data sets of long-term observations from all parts of WCJ. In this study, we used the observation data from 136 air quality monitoring stations in WCJ, where $\mathrm{O}_{\mathrm{x}}$ was measured continuously during 19852005. All of the stations are located at altitudes of less than $1 \mathrm{~km}$ above mean sea level.

At all selected stations, $\mathrm{O}_{\mathrm{x}}$ was measured by the KI method before 1997. Subsequently, the UV method was gradually introduced; and about $18 \%, 51 \%$, and $62 \%$ of the stations were using the UV method in 2000, 2003, and 2005, respectively. In order to determine the extent to which the use of different monitoring instruments influenced the observation values, measurements by both methods at the same time and place are required. However, we did not have such data sets. Thus, we selected 10 pairs of neighboring stations at which (1) the correlation coefficient of springtime $\mathrm{O}_{\mathrm{x}}$ between pairs of stations, measured by the KI method simultaneously at both stations of each pair, was larger than 0.8 , and (2) the UV method was introduced at only one station of each pair or at both stations but in different years. Then, the relationship between $\mathrm{O}_{\mathrm{x}}$ observations made at the same time at neighboring station by the two methods was obtained as follows:

$\mathrm{O}_{\mathrm{x}_{-} \mathrm{UV}}=0.99 \times \mathrm{O}_{\mathrm{x}_{-} \mathrm{KI}}+1.8, \quad(r=0.79)$,

where $\mathrm{O}_{\mathrm{x}_{-} \mathrm{UV}}$ and $\mathrm{O}_{\mathrm{x}_{-} \mathrm{KI}}$ are springtime $\mathrm{O}_{\mathrm{x}}$ mixing ratios [ppbv] observed by UV and KI methods, respectively. Although this comparison does not use measurements made at exactly the same place, the difference between $\mathrm{O}_{\mathrm{x}}$ mixing ratios observed by the KI method and those observed by the UV method seems to be small. Furthermore, Maeda et al. (1997) reported that the concentration of peroxyacetyl nitrate obtained by the KI method is about one-fifteenth the actual concentration; thus, the sensitivity of this method to $\mathrm{O}_{\mathrm{x}}$ other than $\mathrm{O}_{3}$ is relatively small. In accordance with these findings, we consider the difference in observation methods to not be a critical problem for our analysis of IAV of springtime $\mathrm{O}_{3}$ over Japan.

Note that the horizontal and vertical resolution of our model is $80 \times 80 \mathrm{~km}^{2}$ and $150 \mathrm{~m}$ at the lowest layer, respectively. $\mathrm{NO}_{\mathrm{x}}$ titration of $\mathrm{O}_{3}$ at ground level can be underestimated in such a relatively coarse grid because of excessive dilution of $\mathrm{NO}_{\mathrm{x}}$ emissions, especially in urban and suburban areas. Therefore, monitoring stations should be classified as urban, suburban, or rural. Unfortunately, no information about site characteristics is available from the stations. In this study, we therefore used $\mathrm{NO}_{\mathrm{x}}$ mixing ratios observed at each station to classify the site. All selected stations observed NO, $\mathrm{NO}_{2}$, and $\mathrm{NO}_{\mathrm{x}}$ by the colorimetry using Saltzman reagent (with Saltzman's coefficient being 0.84) or by the chemiluminescent method using $\mathrm{O}_{3}$ (Ministry of the Environment of Japan, 2007). Using the 21-year average (during 19852005) of springtime $\mathrm{NO}_{\mathrm{x}}$ mixing ratios, we classified the stations as follows: urban $\left(\mathrm{NO}_{\mathrm{x}}>30 \mathrm{ppbv} ; 17 \%\right)$, suburban $\left(15 \mathrm{ppbv}<\mathrm{NO}_{\mathrm{x}}<30 \mathrm{ppbv} ; 65 \%\right.$, or rural $\left(\mathrm{NO}_{\mathrm{x}}<15 \mathrm{ppbv}\right.$; $18 \%)$. This classification is used in the next section.

\subsubsection{Observed and simulated interannual variation}

Figure 5a compares the time series of daytime springtime surface mixing ratios of observed $\mathrm{O}_{\mathrm{x}}$ averaged over urban, suburban, and rural areas with those of simulated $\mathrm{O}_{3}$ over WCJ for the $\mathrm{E}_{y y} \mathrm{M}_{y y}$ scenario during 1985-2005. To calculate the springtime means of observed $\mathrm{O}_{\mathrm{x}}$ over urban, suburban, and rural areas, we first calculated the springtimeaveraged mixing ratios at each station using daytime data (between 09:00 and 15:00 h). Then, we calculate mean values from the station averages in each area with equal weight. As expected, observed $\mathrm{O}_{\mathrm{x}}$ values were smallest over urban areas and largest over rural areas. On average, $\mathrm{O}_{\mathrm{x}}$ mixing ratios over suburban and rural areas were respectively about 5 and $10 \mathrm{ppbv}$ larger than those over urban areas. However, simulated $\mathrm{O}_{3}$ mixing ratios over WCJ were still about 5-10 ppbv larger than observed $\mathrm{O}_{\mathrm{x}}$ values over rural areas, which suggests that even stations at sites defined as rural 
6294 J. Kurokawa et al.: Meteorological variability on interannual variations of springtime boundary layer ozone over Japan

(a) Mixing ratio of daytime $\mathrm{O}_{\mathrm{x}}(\mathrm{OBS}), \mathrm{O}_{3}\left(\mathrm{E}_{\mathrm{y} y \mathrm{M}} \mathrm{M}_{\mathrm{y} y}\right)$, and $\mathrm{O}_{\mathrm{x}}\left(\mathrm{OBS}\right.$ and $\left.\mathrm{E}_{\mathrm{y} y \mathrm{M}} \mathrm{M}_{\mathrm{y} y}\right)$

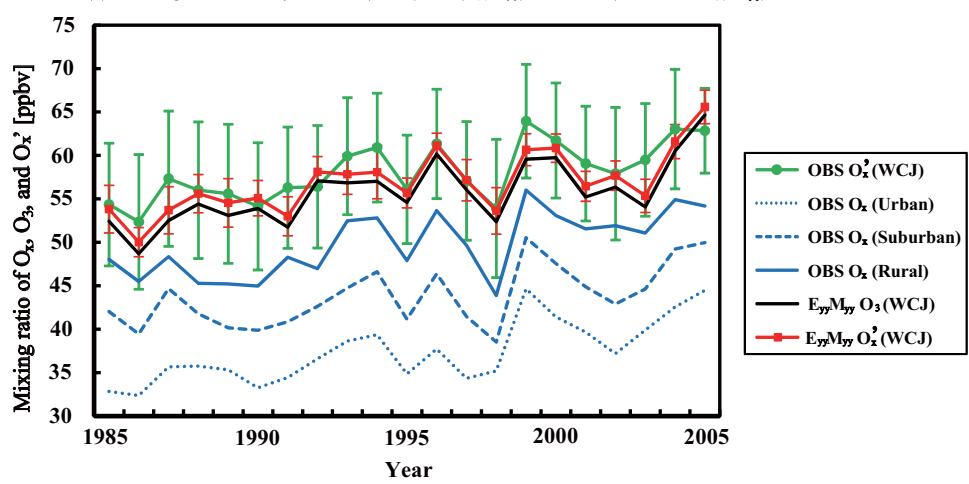

(b) Anomalies of $\mathrm{O}_{\mathrm{x}}(\mathrm{OBS})$ and $\mathrm{O}_{3}\left(\mathrm{E}_{\mathrm{y} y \mathrm{M}} \mathrm{M}_{\mathrm{y}}\right.$ and $\left.\mathrm{E}_{00} \mathrm{M}_{\mathrm{y} y \mathrm{y}}\right)$ with emissions over WCJ and CEC

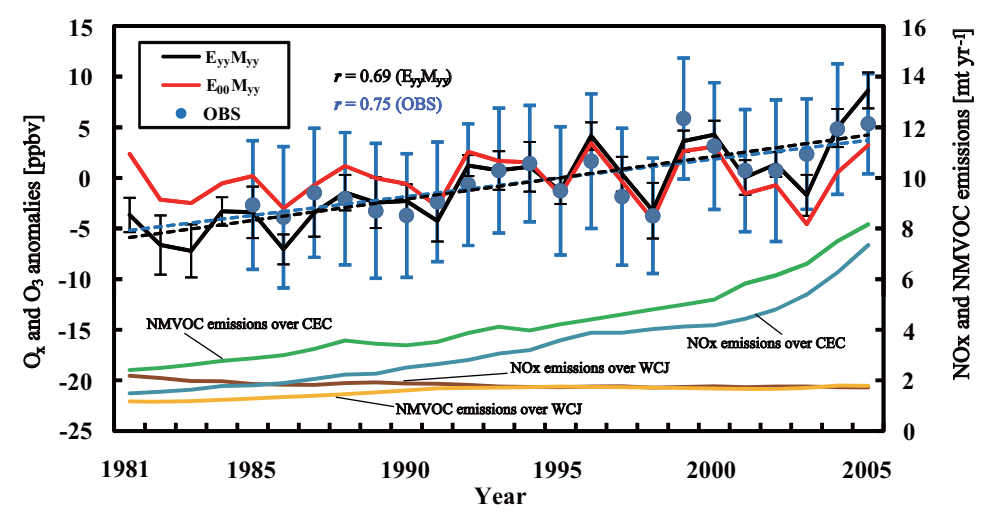

Fig. 5. (a) Time series of the daytime springtime surface mixing ratios of observed $\mathrm{O}_{\mathrm{x}}$ and simulated $\mathrm{O}_{3}$ for the $\mathrm{E}_{y y} \mathrm{M}_{y y}$ scenario during 1985-2005. Simulated $\mathrm{O}_{3}$ mixing ratios are averaged over WCJ (black line), and observed $\mathrm{O}_{\mathrm{x}}$ values are the average of measurements over urban (blue dotted line), suburban (blue dashed line), and rural (blue solid line) areas. The time series of daytime springtime surface $\mathrm{O}_{\mathrm{x}}$ ' over WCJ calculated with observed (green line) and simulated (red line) results are also plotted. (b) Time series of anomalies of springtime observed surface $\mathrm{O}_{\mathrm{x}}$ (blue points) and simulated $\mathrm{BL} \mathrm{O}_{3}$ for the $\mathrm{E}_{y y} \mathrm{M}_{y y}$ (black line) and $\mathrm{E}_{00} \mathrm{M}_{y y}$ (red line) scenarios averaged over WCJ during 1981-2005. Anomalies are defined as deviations from the values averaged over 1985-2005. The blue regression line and correlation coefficient $(r)$ are for observations, and the black ones are for simulations by $\mathrm{E}_{y y} \mathrm{M}_{y y}$. Emissions of $\mathrm{NO}_{\mathrm{x}}$ and $\mathrm{NMVOC}$ over WCJ and those over CEC are also shown. Note that the whiskers denote 1 standard deviation. Standard deviation of observations was calculated from the springtime-averaged values at each station. That of simulations was based on the values of springtime mean at each grid point over WCJ.

might be influenced by air masses from neighboring urban or suburban areas.

In order to further investigate the cause of differences between observed and simulated results, we defined $\mathrm{O}_{\mathrm{x}}$ ' after Sadanaga et al. (2008) as follows:

$\left[\mathrm{O}_{\mathrm{x}}^{\prime}\right]=\left[\mathrm{O}_{3}\right]+\left[\mathrm{NO}_{2}\right]-0.1 \times\left[\mathrm{NO}_{\mathrm{x}}\right]$.

For $\left[\mathrm{O}_{3}\right]$, mixing ratios of observed $\mathrm{O}_{\mathrm{x}}$ or simulated $\mathrm{O}_{3}$ were used. The third term on the right side of Eq. (2) accounts for primary emissions of $\mathrm{NO}_{2}$, which means that $\mathrm{O}_{\mathrm{x}}$ ' is the sum of $\mathrm{O}_{3}$ and $\mathrm{NO}_{2}$ generated secondarily by the oxidation of $\mathrm{NO}$ in the atmosphere. The time series of daytime springtime surface $\mathrm{O}_{\mathrm{x}}$ ' over WCJ calculated from model simulations and observations at all stations are also compared in Fig. 5a. As with $\mathrm{O}_{\mathrm{x}}$, we first calculated the springtime-averaged $\mathrm{O}_{\mathrm{x}}$ ' at each station using daytime data. Then, we calculated the mean and standard deviation from the station averages with equal weight. Absolute values of simulated $\mathrm{O}_{\mathrm{x}}$ ' agreed well with the observed values although the observed results for several years were higher. Differences between simulated $\mathrm{O}_{\mathrm{x}}{ }^{\prime}$ and $\mathrm{O}_{3}$ were very small. On the other hand, observed mixing ratios of $\mathrm{O}_{\mathrm{x}}$ ' were much larger than those of $\mathrm{O}_{\mathrm{x}}$ by about $15 \mathrm{ppbv}$ on average. These results indicate that differences between observed $\mathrm{O}_{x}$ and simulated $\mathrm{O}_{3}$ over WCJ are caused mainly by the dilution of $\mathrm{NO}_{\mathrm{x}}$ emissions in the coarse model grid of this study.

Note that there was no large systematic overestimate of simulated $\mathrm{O}_{3}$ at the remote or rural stations over East Asia in Fig. 2. In contrast, $\mathrm{O}_{\mathrm{x}}$ observations at air quality monitoring stations of Japan used in this section were overestimated even in the rural areas (Fig. 5a). As mentioned above, monitoring sites defined as rural in this section might be affected by neighboring urban or suburban air masses. We found that average $\mathrm{NO}_{\mathrm{x}}$ mixing ratios during 1985-2005 were greater 
than $10 \mathrm{ppbv}$ at the majority of rural stations. At Japanese remote monitoring sites of EANET in Fig. 2, springtime $\mathrm{NO}_{\mathrm{x}}$ mixing ratios were about $0.5-2.0 \mathrm{ppbv}$ and thus, the effects of $\mathrm{NO}_{\mathrm{x}}$ titration were considered to be small. We did not have $\mathrm{NO}_{\mathrm{x}}$ observation data at other stations in Fig. 2. With respect to Lin'an site, large model overestimation of observed $\mathrm{O}_{3}$ might be attributed to the underestimation of $\mathrm{NO}_{\mathrm{x}}$ titration of $\mathrm{O}_{3}$ in the coarse model grid of this study, as described in Sect. 3.1. Simulated $\mathrm{O}_{3}$ at Hok Tsui, Pohang, and Wanli sites slightly overestimated observations. These sites also might be influenced by polluted air masses from the neighboring industrialized regions although they were located in remote areas. However we suspect that springtime $\mathrm{NO}_{\mathrm{x}}$ concentrations at these sites were smaller than those at rural monitoring stations of Japan used in Fig. 5a and thus, influences of excessive dilution of $\mathrm{NO}_{\mathrm{x}}$ emissions on $\mathrm{NO}_{\mathrm{x}}$ titration of $\mathrm{O}_{3}$ in the model were relatively small.

With respect to the IAV of observations, it is interesting that all observation types, namely, $\mathrm{O}_{\mathrm{x}}$ in urban, suburban, and rural areas and $\mathrm{O}_{\mathrm{x}}^{\prime}$ over WCJ show very similar trends. This result suggests that the IAV of $\mathrm{O}_{3}$ over WCJ is affected more by large-scale factors than by local ones. Both observed and simulated results show larger year-to-year variations than the annual rate of increase of the long-term trend. Simulated results reproduced the observed local minima in 1986, 1995, and 1998 and the local maxima in 1996 and 19992000. Observed mixing ratios decreased from 1996 to 1998 and from 2000 to 2002, in contrast to the long-term trend, and these features are also well reproduced by model simulations. The amplitude of the IAV during 1987 and 1991 was relatively small in both observed and simulated results. Simulated mixing ratios show a large increase from 1991 to 1992 and a decrease from 2002 to 2003, neither of which is found in the observation data. However, CMAQ generally reproduced well the observed IAV of springtime surface $\mathrm{O}_{\mathrm{x}}$ mixing ratios over WCJ.

Figure $5 \mathrm{~b}$ compares the time series of observed springtime surface $\mathrm{O}_{\mathrm{x}}$ anomalies averaged over WCJ with those of the springtime $\mathrm{BL}_{3}$ simulated by $\mathrm{E}_{y y} \mathrm{M}_{y y}$ for 1985-2005. Data from all hours of the day were used for the calculation of the springtime mean and standard deviation. The anomalies used in this section for comparing observed and simulated results are defined as deviations from the values averaged over 1985-2005. The IAV of anomalies of observed surface $\mathrm{O}_{x}$ and $\mathrm{BL} \mathrm{O}_{3}$ simulated by $\mathrm{E}_{y y} \mathrm{M}_{y y}$ is very similar with that of daytime mixing ratios shown in Fig. 5a. We also compared the simulated springtime surface and $\mathrm{BL} \mathrm{O}_{3}$ (not shown) and found that their anomalies were almost the same over WCJ. In addition, the horizontal distribution of BL $\mathrm{O}_{3}$ was very similar to that of surface $\mathrm{O}_{3}$, although absolute $\mathrm{BL}_{3}$ mixing ratios over WCJ were larger than the surface values by about $2.5 \mathrm{ppbv}$ on average. Hereafter, we analyze the simulated results of springtime $\mathrm{BL}_{3}$ calculated using data from all times of day. We also compared the IAV of springtime $\mathrm{BL}_{3}$ anomalies simulated by $\mathrm{E}_{y y} \mathrm{M}_{y y}$ (Fig. 5b, black line) with that simulated by $\mathrm{E}_{00} \mathrm{M}_{y y}$ (red line). In both scenarios, the IAV of $\mathrm{O}_{3}$ anomalies shows clearly similar patterns, especially the large year-to-year variations. As described in Sect. 2.2, the $\mathrm{E}_{00} \mathrm{M}_{y y}$ scenario uses the fixed emissions for 2000 and the meteorological fields for each year. Therefore, these results suggest that the short-term IAV of springtime surface and $\mathrm{BL} \mathrm{O}_{3}$ over WCJ is determined mainly by the meteorological variability. Note that anomalies of both observation and simulation by $\mathrm{E}_{y y} \mathrm{M}_{y y}$ show clear increasing trends, with respective rates of increase of about 0.37 and 0.42 [ppbv/year]. Both trends were calculated by least-squares linear fitting and considered statistically significant at p-values less than 0.01 . Emissions of $\mathrm{NO}_{\mathrm{x}}$ and NMVOC over WCJ and CEC were calculated from input emissions for $\mathrm{E}_{y y} \mathrm{M}_{y y}$ and are presented in Fig. 5b. No long-term increasing trend of $\mathrm{O}_{3}$ is found in either the results simulated by $\mathrm{E}_{00} \mathrm{M}_{y y}$ or the calculated emissions over WCJ, whereas both $\mathrm{NO}_{\mathrm{x}}$ and NMVOC emissions over CEC clearly increased during 1985-2005. These results suggest that the increase in the observed $\mathrm{O}_{\mathrm{x}}$ anomalies was caused by the recent increase in anthropogenic emissions in East Asia, especially in China (Ohara et al., 2008).

\subsection{Years of high and low springtime $\mathrm{BL} \mathrm{O}_{3}$ over western and central Japan}

In some years, the springtime $\mathrm{BL}_{3}$ over WCJ simulated by $\mathrm{E}_{00} \mathrm{M}_{y y}$ is much higher or lower than in other years, even though the same emission data set was used (Fig. 5b). To analyze these features, in this section we define "high (low) $\mathrm{O}_{3}$ over WCJ years" as the top (bottom) 5 years between 1981 and 2005 with respect to the springtime $\mathrm{BL} \mathrm{O}_{3}$ anomalies simulated by $\mathrm{E}_{00} \mathrm{M}_{y y}$. The high $\mathrm{O}_{3}$ over WCJ years are 1992 , 1996, 1999, 2000, and 2005. The low $\mathrm{O}_{3}$ over WCJ years are 1983, 1986, 1991, 1998, and 2003. Figure 6 shows the composite springtime $\mathrm{BL} \mathrm{O}_{3}$ fields (a and b), their anomalies (c and $d$ ), and springtime surface pressure anomalies (e and $f$ ) for the high (a, c, and e) and low (b, d, and f) $\mathrm{O}_{3}$ over WCJ years. The overlaid vectors in Fig. $6 \mathrm{a}$ and $\mathrm{b}$ are the composite springtime wind fields in the BL, and those in Fig. 6c, d, $\mathrm{e}$, and $\mathrm{f}$ are the composite wind field anomalies. In this and the following sections, all analyses are based on the results simulated by $\mathrm{E}_{00} \mathrm{M}_{y y}$ and anomalies are redefined as the deviations from values averaged over 1981-2005.

First, we describe the general features of the composite field of high $\mathrm{O}_{3}$ over WCJ years. The area of high $\mathrm{O}_{3}$ over CEC, the Korean peninsula, and Japan (Fig. 6a) is slightly larger and shifted southward compared with the climatological field (Fig. 4b). Correspondingly, high positive $\mathrm{O}_{3}$ anomalies are widespread over the area south of the high $\mathrm{O}_{3}$ region from the eastern coast of China to south of the Japanese Islands (Fig. 6c). WCJ is near the center of the high $\mathrm{O}_{3}$ area and on the edge of the high positive anomaly region. The mean wind field (Fig. 6a) and mean wind field anomalies (Fig. 6c and e) over WCJ show that westerly components 
Springtime $\mathrm{BL} \mathrm{O}_{3}$ and wind fields

(a) High Years

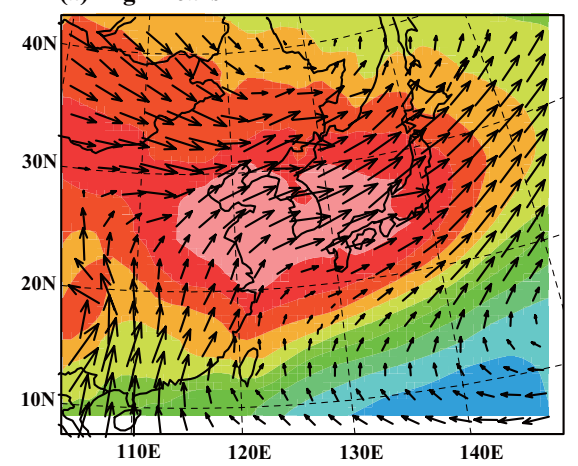

(b) Low Years

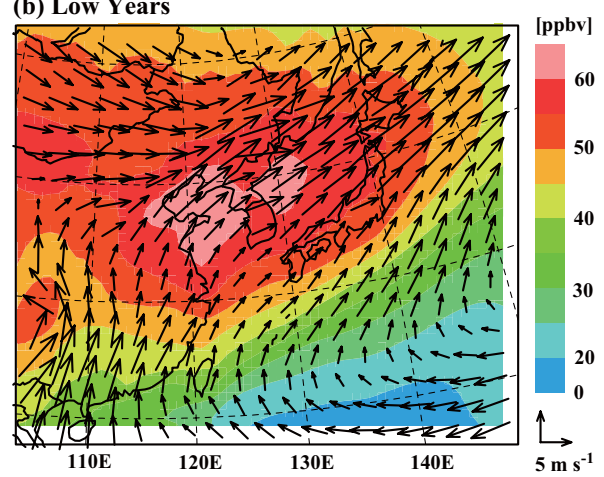

Anomalies of springtime $\mathrm{BL}_{3}$ and wind fields

(c) High Years

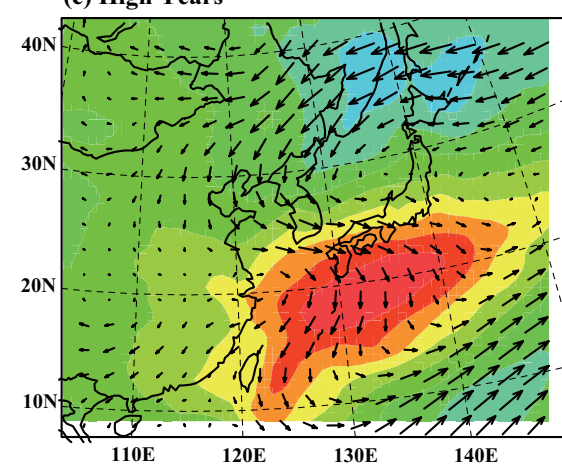

(d) Low Years

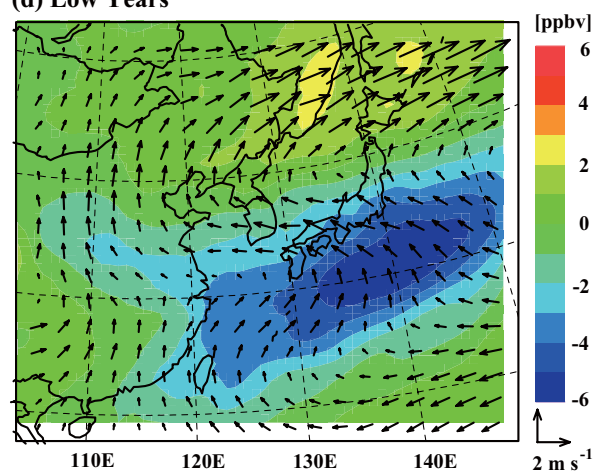

Anomalies of surface pressure and wind fields

(e) High Years

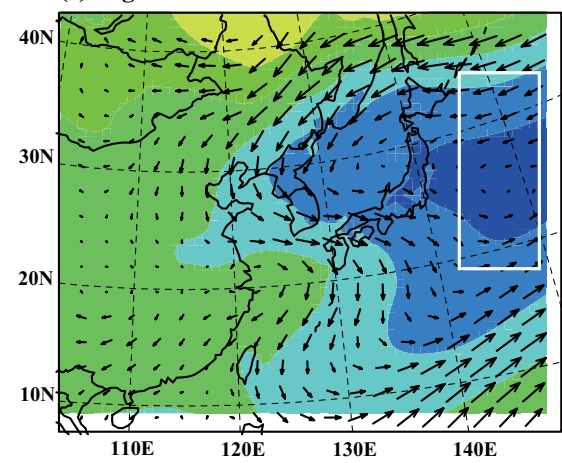

(f) Low Years

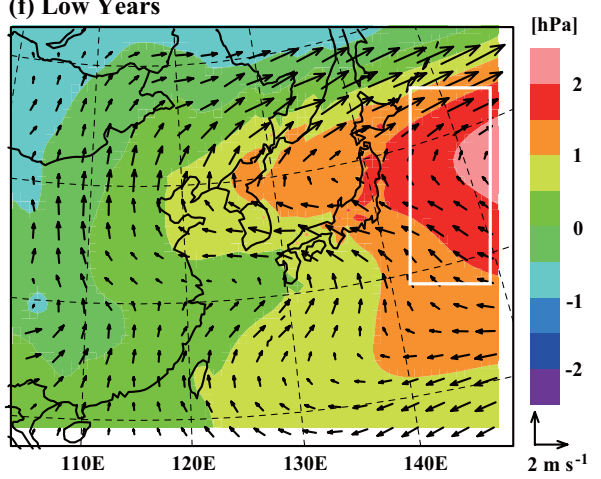

Fig. 6. Composite spatial distributions of springtime $\mathrm{BL}_{3}(\mathbf{a})$, their anomalies (c), and surface pressure anomalies during high $\mathrm{O}_{3}$ over WCJ years (e) (High Years). The same information but during low $\mathrm{O}_{3}$ over WCJ years (Low Years) is shown in (b), (d), and (f), respectively. Vectors in (a) and (b) indicate the composite springtime wind field in the BL, and those in (c), (d), (e), and (f) are the wind anomalies. High (low) $\mathrm{O}_{3}$ over WCJ years were defined as the top (bottom) 5 years among the springtime $\mathrm{BL} \mathrm{O}_{3}$ anomalies over WCJ between 1981 and 2005. The white box in (e) and (f) shows the area where the area-weighted surface pressure anomaly (ASPA) was calculated. The $\mathrm{E}_{00} \mathrm{M}_{y y}$ scenario was used for the model simulation. Anomalies are defined as deviations from averaged values during 1981-2005.

are stronger and southerly components are weaker than the corresponding components of the climatological wind field. This suggests that in high $\mathrm{O}_{3}$ over WCJ years, WCJ is strongly influenced by continental-Asian outflow but less influenced by maritime air masses from the Pacific Ocean. The northeastern area, including northern Japan, is outside the high $\mathrm{O}_{3}$ area, and weak negative anomalies of $\mathrm{O}_{3}$ are found there. The westerly component of the wind fields in this area is weaker than the average, which suggests relatively small influences of continental-Asian air masses. With respect to the surface pressure anomalies, negative values are widespread around the Japanese Islands and, especially, over the Pacific Ocean east of Japan (Fig. 6e). 
With respect to the low $\mathrm{O}_{3}$ over WCJ years, the high $\mathrm{O}_{3}$ area is somewhat smaller and shifted northward (Fig. 6b) compared to the climatology (Fig. 4b). WCJ is not near the center of the high $\mathrm{O}_{3}$ area. The area of negative $\mathrm{O}_{3}$ anomalies (Fig. 6d) almost coincides with the positive anomaly region in the high $\mathrm{O}_{3}$ over WCJ years (Fig. 6c). WCJ is on the edge of the negative anomaly region. The mean wind field (Fig. 6b) and its anomalies (Fig. 6d and f) display weaker westerly components and stronger southerly components over WCJ compared with the climatological field. Thus, these results suggest that in low $\mathrm{O}_{3}$ over WCJ years, the influence of the continental-Asian outflow on WCJ is smaller and that of maritime air masses from the Pacific Ocean is larger than during ordinary years. The positive $\mathrm{O}_{3}$ anomalies over the northeastern region might reflect relatively stronger westerly winds, but the values are small. In contrast to the high $\mathrm{O}_{3}$ over WCJ years, surface pressure anomalies are positive (Fig. 6f). However, the positive anomalies appear in almost the same area as the negative anomalies shown in Fig. 6e.

We also investigated the chemical production, chemical loss, and net chemical production of simulated $\mathrm{O}_{3}$ over East Asia, and the results are presented in the supplementary material (http://www.atmos-chem-phys.net/ 9/6287/2009/acp-9-6287-2009-supplement.pdf). However, we found no obvious influences of chemical processes on the IAV of springtime $\mathrm{BL} \mathrm{O}_{3}$ over WCJ. There is no relationship between $\mathrm{O}_{3}$ anomalies and the net chemical production of $\mathrm{O}_{3}$ over WCJ. Anomalies of net chemical production of $\mathrm{O}_{3}$ over CEC were positively correlated with $\mathrm{O}_{3}$ anomalies over WCJ. However, the slope of the regression line was not large (Fig. S2b in the supplementary material: http://www.atmos-chem-phys.net/9/6287/ 2009/acp-9-6287-2009-supplement.pdf), and, furthermore, the correlation coefficient was relatively small (0.37). Thus, in this study, we did not focus on the effects of chemical processes on the springtime $\mathrm{BL}_{3}$ anomalies over WCJ.

Finally, on the basis of our findings, we identify the processes controlling the springtime $\mathrm{BL}_{3}$ concentrations over WCJ as follows:

\section{(1) High $\mathrm{O}_{3}$ over WCJ years}

Polluted air masses from continental Asia tend to be transported directly to WCJ by the strong westerly component of the wind field. Meanwhile, the inflow of clean maritime air masses from the Pacific Ocean to WCJ is small because southerly winds around WCJ are weak. As a result, the springtime $\mathrm{BL} \mathrm{O}_{3}$ concentrations over WCJ are higher than during ordinary years. Large negative surface pressure anomalies are present over the $\mathrm{Pa}$ cific Ocean east of Japan.

\section{(2) Low $\mathrm{O}_{3}$ over $\mathrm{WCJ}$ years}

The influence of the continental-Asian outflow tends to be small because the westerly component of the wind fields around WCJ is relatively weak. On the other hand, southerly winds around WCJ are comparatively strong, and efficiently transport clean air masses from the Pacific Ocean to WCJ. Consequently, the springtime $\mathrm{BL} \mathrm{O}_{3}$ concentration over $\mathrm{WCJ}$ is lower than that during an average year. Large positive surface pressure anomalies are present over the Pacific Ocean east of Japan.

It is interesting that large negative and positive surface pressure anomalies respectively occur in almost the same region during high and low $\mathrm{O}_{3}$ over WCJ years (Fig. 6e and $\mathrm{f}$, respectively). Thus, as a reference parameter, we calculated the area-weighted surface pressure anomaly (ASPA) in the springtime over the region within the following coordinates (white box in Fig. 6e and f): $141.62^{\circ} \mathrm{E}, 29.31^{\circ} \mathrm{N}$; $149.85^{\circ} \mathrm{E}, 27.49^{\circ} \mathrm{N} ; 146.82^{\circ} \mathrm{E}, 44.36^{\circ} \mathrm{N}$; and $156.02^{\circ} \mathrm{E}$, $41.76^{\circ} \mathrm{N}$. Note that the largest springtime surface pressure anomalies in the NCEP/NCAR Reanalysis 1 data sets are found in the region $30-45^{\circ} \mathrm{N}, 180-150^{\circ} \mathrm{W}$. Because that region is outside the model domain of CMAQ designed for this study, we examined the relationship between the ASPA and the averaged anomalies in the area of $30-45^{\circ} \mathrm{N}, 180$ $150^{\circ} \mathrm{W}$ and found a good positive correlation between them $(r=0.83)$. We hypothesized that when the ASPA value is negative (positive), $\mathrm{O}_{3}$ over WCJ should be higher (lower) than during an ordinary year. We examine this hypothesis in the following sections.

\subsection{Relationships among springtime $\mathrm{BL} \mathrm{O}_{3}$ over western and central Japan, continental-Asian outflow, and surface pressure anomaly}

Time series of springtime ASPA and $\mathrm{BL}_{3}$ anomalies over WCJ during 1981-2005 are shown in Fig. 7a. In general, ASPA and $\mathrm{BL} \mathrm{O}_{3}$ anomalies are negatively correlated especially when the absolute value of ASPA is large such as in 1998 and 2000. On the other hand, no clear relation is observed when the value of ASPA is small, such as during the late 1980s. Figure $7 \mathrm{~b}$ shows a scatter plot and regression lines between springtime ASPA and $\mathrm{BL}_{3}$ anomalies over WCJ. The regression lines for all data and for large ASPA data (larger than $1 \mathrm{hPa}$ ) have similar negative slopes. However, as expected, the correlation coefficient $(r=-0.85)$ for large ASPA data has a larger negative value than that for all data $(r=-0.79)$. These results suggest that ASPA is a good reference parameter for springtime $\mathrm{BL}_{3}$ over WCJ, especially when the absolute value of ASAP is large.

To investigate the relationships among the IAV of $\mathrm{O}_{3}$ over WCJ, inflow $\mathrm{O}_{3}$ fluxes to WCJ, and ASPA, we calculated the anomalies of springtime $\mathrm{BL}_{3}$ fluxes along sections at the western and southern boundaries of WCJ ( $\mathrm{L}_{\mathrm{WJ}}$ and $\mathrm{L}_{\mathrm{SJ}}$, respectively; see Fig. 1). A large $\mathrm{O}_{3}$ flux anomaly along 

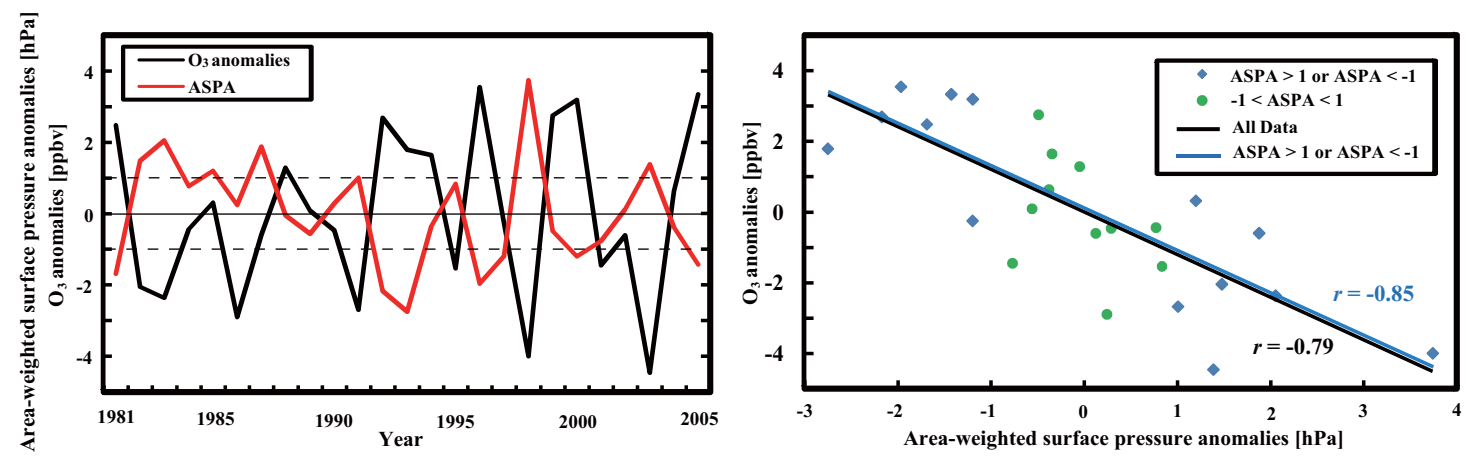

Fig. 7. Time series (left) and scatter plot (right) of springtime $\mathrm{BL} \mathrm{O}_{3}$ anomalies and ASPA during 1981-2005. Horizontal dashed lines indicate $\pm 1 \mathrm{hPa}$ of ASPA. Blue and green points respectively represent absolute values of ASPA larger (large ASPA data; 14 data points) and smaller (11 data points) than $1 \mathrm{hPa}$. The black regression line is for all data ( 25 data points), and the blue one is for large ASPA data. The simulation scenario and the definition of anomalies are the same as in Fig. 6.

(a) $\mathrm{O}_{3}$ anomalies and normalized $\mathrm{FAw}$

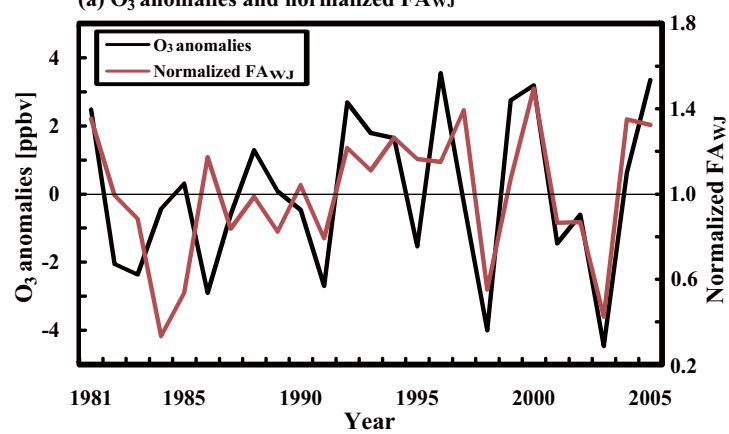

(b) $\mathrm{O}_{3}$ anomalies and normalized FAsJ

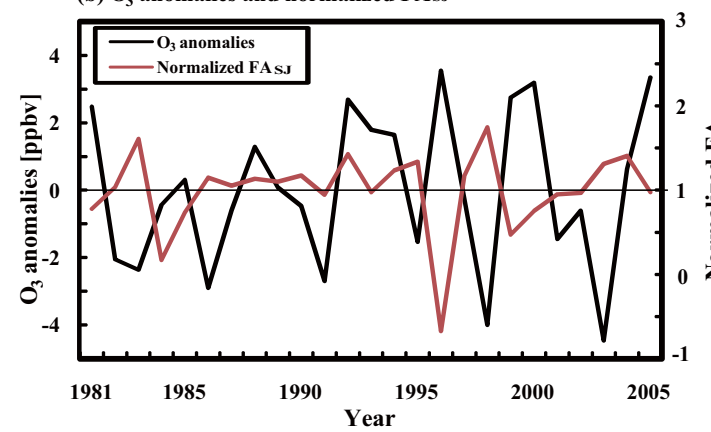

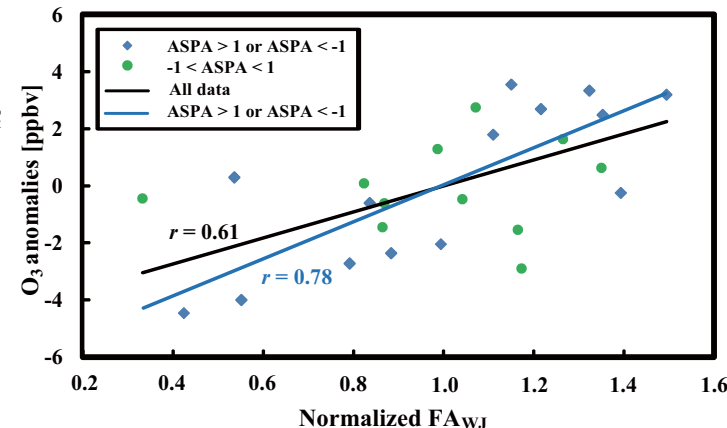

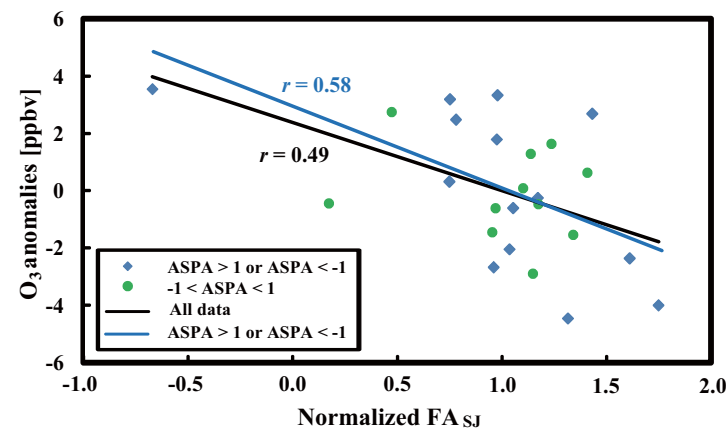

Fig. 8. (a) Time series (left) and scatter plot (right) of $\mathrm{O}_{3}$ anomalies over $\mathrm{WCJ}$ and $\mathrm{O}_{3}$ flux anomalies across the section along $\mathrm{L}_{W J}\left(\mathrm{FA} \mathrm{WJ}_{\mathrm{W}}\right)$ in the springtime BL between 1981 and 2005. (b) The same as in (a) but with $\mathrm{O}_{3}$ flux anomalies across the section along $\mathrm{L}_{\mathrm{SJ}}(\mathrm{FA} \mathrm{SJ}$ ). See Fig. 1 for the definition of $\mathrm{L}_{\mathrm{WJ}}$ and $\mathrm{L}_{\mathrm{SJ}}$. Values of FA $\mathrm{WJ}_{\mathrm{J}}$ and FA $\mathrm{SJ}$ are normalized relative to the respective 25-year average. The colors of points and lines are the same as in Fig. 7. The simulation scenario and the definition of anomalies are the same as in Fig. 6.

$\mathrm{L}_{\mathrm{WJ}}\left(\mathrm{FA}_{\mathrm{WJ}}\right.$ ) means that the influence of the continentalAsian outflow, which transports high $\mathrm{O}_{3}$ air masses to WCJ, is large. In contrast, when the $\mathrm{O}_{3}$ flux anomaly along $\mathrm{L}_{\mathrm{SJ}}$ $\left(\mathrm{FA}_{\mathrm{SJ}}\right)$ is large, the $\mathrm{O}_{3}$ concentration over WCJ is decreased by clean maritime air transported from the Pacific Ocean. Figures $8 \mathrm{a}$ and $\mathrm{b}$ display the time series of $\mathrm{O}_{3}$ anomalies over WCJ and FA ${ }_{W J}$ and FASJ, respectively, with the right- hand panels showing the corresponding scatter diagrams and regression lines. Values of $F A_{\mathrm{WJ}}$ and $\mathrm{FA}_{\mathrm{SJ}}$ are normalized relative to the respective 25-year average.

$\mathrm{FA}_{\mathrm{WJ}}$ and $\mathrm{O}_{3}$ anomalies over WCJ are generally positively correlated $(r=0.61)$; both the correlation coefficient $(r=0.78)$ and the slope of regression line for large ASPA data are larger than those for all data. On the other hand, $\mathrm{FA}_{\mathrm{SJ}}$ and $\mathrm{O}_{3}$ 

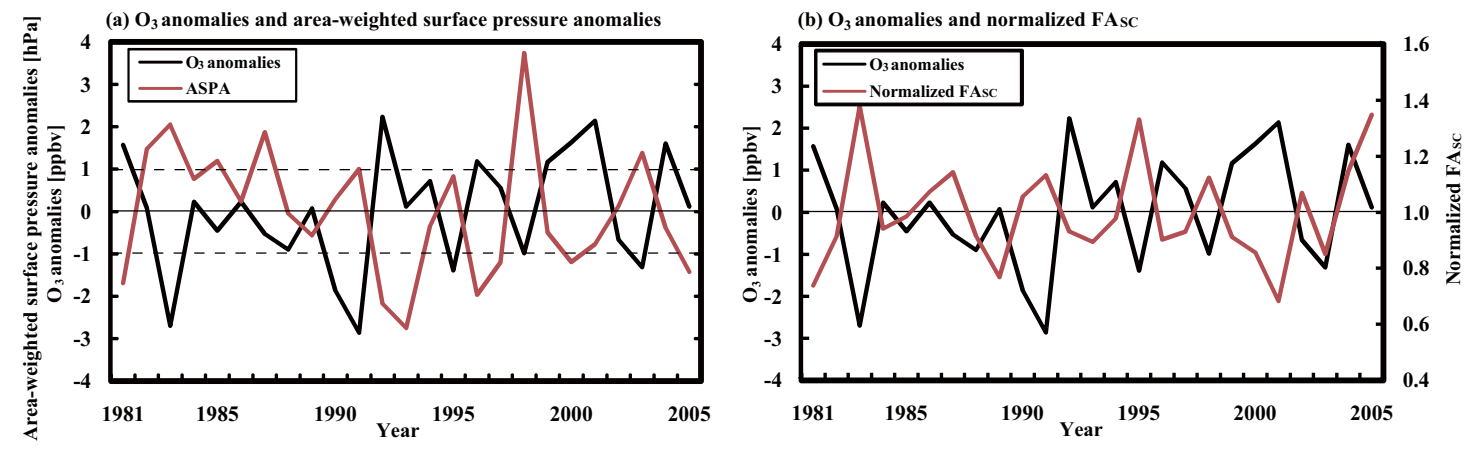

Fig. 9. (a) Time series of springtime $\mathrm{BL} \mathrm{O}_{3}$ anomalies over CEC and ASPA between 1981 and 2005. (b) The same as in (a) but with springtime $\mathrm{BL} \mathrm{O}_{3}$ flux anomalies across the section along $\mathrm{L}_{\mathrm{SC}}(\mathrm{FA} \mathrm{SC})$. See Fig. 1 for the definition of $\mathrm{L}_{\mathrm{SC}}$. Values of FA $\mathrm{SC}$ are normalized relative to the 25-year average. The simulation scenario and the definition of anomalies are the same as in Fig. 6.

anomalies over WCJ are negatively correlated $(r=-0.49)$. Similar to FAWJ, both the absolute value of $r(-0.58)$ and the slope of the regression line are slightly larger for large ASPA data. We also examined the relations between ASPA and FA ${ }_{W J}$ and between ASPA and FA $A_{S J}$. As expected, FA ${ }_{W J}$ and $\mathrm{FA}_{\mathrm{SJ}}$ are respectively negatively and positively correlated with ASPA. For FAwJ $r$ (all data, large ASPA data) is $(-0.65,-0.78)$ and for $\mathrm{FA}_{\mathrm{SJ}} r$ is $(0.39,0.48)$. These results indicate that when the transport of $\mathrm{O}_{3}$ from continental Asia is large, transport from the Pacific Ocean tends to be small, and vice versa, especially when the absolute value of ASPA is large. The IAV of $\mathrm{O}_{3}$ over WCJ is affected by transport of both high- $\mathrm{O}_{3}$ air masses from continental Asia and clean maritime air from the south to WCJ. The correlation of $\mathrm{O}_{3}$ over WCJ with $F A_{W J}$ is stronger than that with $\mathrm{FA}_{\mathrm{SJ}}$, which suggests that the IAV of springtime $\mathrm{BL} \mathrm{O}_{3}$ over WCJ is more sensitive to the continental-Asian outflow. However, there have been some years when the maritime air masses had a larger effect. The $\mathrm{O}_{3}$ anomalies over WCJ in 1997 were smaller than those in 1996 even though FAWJ in 1997 was larger. This is because FA $\mathrm{SJ}$ in 1996 was much smaller than in 1997.

We also investigated the IAV of springtime $\mathrm{BL} \mathrm{O}_{3}$ over CEC (region as defined in Fig. 1). Figure 9a shows the IAV of $\mathrm{O}_{3}$ anomalies over CEC and ASPA between 1981 and 2005. In general, they are negatively correlated $(r=-0.65$ and -0.71 for all data and large ASPA data, respectively). The wind field anomalies suggest that when ASPA has a large positive value (i.e. low $\mathrm{O}_{3}$ over WCJ years; see Sect. 3.4 and Fig. 6d and f), relatively strong southerly winds around the southern boundary of CEC ( $\mathrm{L}_{\mathrm{SC}}$, see Fig. 1) transport lower $\mathrm{O}_{3}$ air from southern China. In contrast, when ASPA has a large negative value (i.e. high $\mathrm{O}_{3}$ over WCJ years; see Sect. 3.4 and Fig. 6c and e), $\mathrm{O}_{3}$ over CEC tends to be higher because the southerly component of winds around $\mathrm{L}_{\mathrm{SC}}$ is comparatively weak. We examined these inferences by plotting the time series of $\mathrm{O}_{3}$ anomalies over $\mathrm{CEC}$ and $\mathrm{O}_{3}$ flux anomalies along section $\mathrm{L}_{\mathrm{SC}}\left(\mathrm{FA}_{\mathrm{SC}}\right)$ in the springtime $\mathrm{BL}$ (Fig. 9b). As expected, the $\mathrm{O}_{3}$ anomalies and $\mathrm{FA}_{\mathrm{SC}}$ are negatively correlated $(r=-0.57$ and -0.61 for all data and large ASPA data, respectively). These results indicate that $\mathrm{O}_{3}$ over CEC is also affected by the meteorological IAV, and they are consistent with the results of $\mathrm{He}$ et al. (2008). In addition, springtime $\mathrm{BL} \mathrm{O}_{3}$ over CEC and WCJ are positively correlated $(r=0.61$ and 0.78 for all data and large ASPA data, respectively). Our examination of the relationship between FA ${ }_{W J}$ and springtime westerly winds in the BL averaged over $\mathrm{L}_{\mathrm{WJ}}$ showed that the correlation coefficient is almost 1 , even when all data are included. This finding indicates that the IAV of FAWJ is not controlled by the IAV of $\mathrm{O}_{3}$ over CEC but mostly by the IAV of westerly winds over $\mathrm{L}_{\mathrm{WJ}}$. However, the recent growth of anthropogenic emissions of $\mathrm{O}_{3}$ precursors in China might strengthen the influence of $\mathrm{O}_{3}$ over CEC on the IAV of $\mathrm{O}_{3}$ over WCJ. This will be examined in a future study. Note that the correlation coefficient between FASJ and springtime southerly winds in the BL averaged over $\mathrm{L}_{\mathrm{SJ}}$ was also almost 1 , which indicates that the IAV of FASJ is also controlled by the IAV of southerly winds over $\mathrm{L}_{\mathrm{SJ}}$.

The results discussed above show that the high (low) springtime $\mathrm{BL} \mathrm{O}_{3}$ anomalies over WCJ can be basically explained by a larger (smaller) influence of the continentalAsian outflow, which transports polluted air masses to WCJ, and a smaller (larger) inflow of clean maritime air masses to WCJ, particularly when the absolute value of ASPA is large. However, there are exceptions. The $\mathrm{O}_{3}$ anomalies over WCJ in 1987 and 1997 were almost average (i.e. zero), although the ASPA value in these years were larger than $1 \mathrm{hPa}$. In these years, the region of large $\mathrm{O}_{3}$ anomalies shifted slightly compared with the composite field (not shown). Moreover, the $\mathrm{O}_{3}$ anomalies in 1986, 1991, and 1999 were relatively large although the absolute values of ASPA of these years were small. The large surface pressure anomalies in these years were also distributed in a slightly different region from the area used to define ASPA (not shown). We believe that in 


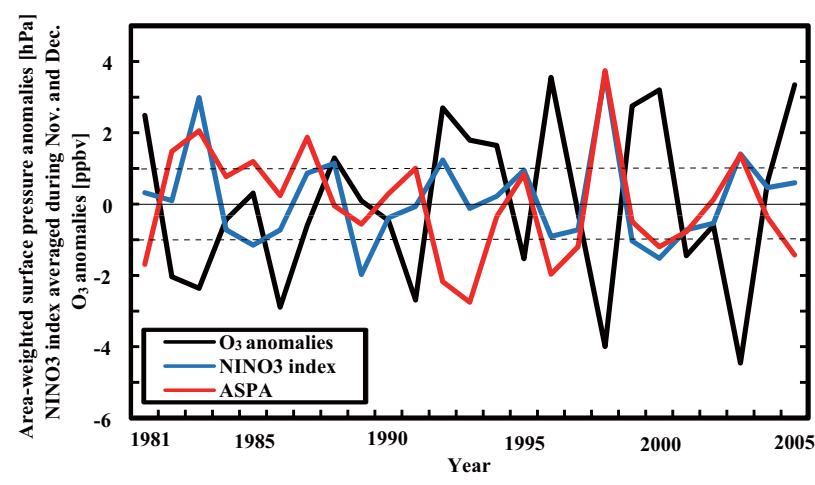

Fig. 10. Time series of springtime $\mathrm{BL} \mathrm{O}_{3}$ anomalies over WCJ, ASPA, and the Niño3 index (NINO3) averaged during November and December of the previous year. Horizontal dashed lines indicate $\pm 1 \mathrm{hPa}$ of ASPA. The simulation scenario and the definition of anomalies are the same as in Fig. 6.

these years the processes affecting the distribution of $\mathrm{O}_{3}$ and their relation to the meteorology were more complicated.

\subsection{Relationship between springtime $\mathrm{BL} \mathrm{O}_{3}$ over western and central Japan and ENSO}

Recently, several studies have reported on the relationship between the IAV of Asian pollution transport and meteorological variations caused by ENSO and their influences on tropospheric $\mathrm{O}_{3}$ (Liu et al., 2003; Liu et al., 2005; Koumoutsaris et al., 2008). However, the impacts of ENSO events on the IAV of the $\mathrm{O}_{3}$ distribution over the northwest Pacific region, including Japan, have not been studied. In this section, we discuss the relationship between the IAV of springtime $\mathrm{BL}_{3}$ over WCJ and ENSO.

Figure 10 shows the time series of ASPA, $\mathrm{O}_{3}$ anomalies over WCJ, and the Niño3 index (hereafter NINO3) during 1981-2005. NINO3, which is the sea surface temperature averaged across the region $5^{\circ} \mathrm{N}-5^{\circ} \mathrm{S}, 150-90^{\circ} \mathrm{W}$ and expressed as monthly anomalies relative to the 1971-2000 means, is one of the commonly used indices in studies of El Niño. We obtained these data from http://www.cpc.noaa. gov/data/indices. In this study, we used values averaged during November and December of the previous year, considering the response time of continental-Asian outflow to ENSO events, after Koumoutsaris et al. (2008). In general, we found positive correlations between NINO3 and ASPA, and negative correlations between $\mathrm{NINO} 3$ and $\mathrm{O}_{3}$ anomalies. We examined these relationships separately for all data and large ASPA data, as in Sect. 3.5. The correlation coefficients for all data (large ASPA data) between NINO3 and ASPA and between $\mathrm{NINO} 3$ and $\mathrm{O}_{3}$ anomalies were 0.52 (0.58) and $-0.40(-0.57)$, respectively. Both relationships are relatively strong when absolute values of ASPA are large, as expected from the results of Sect. 3.5. This result suggests that the high and low $\mathrm{O}_{3}$ over WCJ years are respectively related to La Niña (small NINO3) and El Niño (large NINO3).

Figure 11 displays mean sea level pressure (MSLP) and cyclone tracks during April and May 1998 and 2000, according to the Japanese 25-year Reanalysis data set (JRA25; Onogi et al., 2007) produced by the Japan Meteorological Agency and the Central Research Institute of the Electric Power Industry. The cyclone detection and tracking algorithm is based on that used by Serreze (1995) and Serreze et al. (1997), except it has been slightly modified for application to the JRA-25 data set. The MSLP data set was interpolated from $1.25^{\circ} \times 1.25^{\circ}$ latitude/longitude grid to the Equal Area Scalable Earth grid over the Northern Hemisphere with a $125-\mathrm{km}$ grid interval. A cyclone center is identified by a local minimum of the interpolated MSLP value. The threshold value of MSLP differences is $0.5 \mathrm{hPa}$.

We chose the years 1998 and 2000 because they were an El Niño year and a La Niña year, respectively, and because lower (1998) and higher (2000) springtime $\mathrm{BL} \mathrm{O}_{3}$ mixing ratios over WCJ were seen in both observed and simulated results (Fig. 5). In 1998, a significantly large-scale highMSLP region, centered at $150^{\circ}-170^{\circ} \mathrm{W}$, appeared over the whole Pacific. In contrast, the corresponding high-MSLP area in 2000 was smaller than that in 1998 and distributed mainly over the eastern Pacific. Therefore, in 2000, MSLP over the western Pacific, including Japan, was much lower than that in 1998. We expected these differences to appear as lower and higher ASPA, as defined in this study (see Sect. 3.4 and white boxes in Fig. 6e and f). The distribution of cyclone tracks around Japan was clearly different between 1998 and 2000. Two major cyclone tracks over East Asia and the northwestern Pacific in 1998 can be identified: (1) a southwest-northeast-oriented course, from the southern coast of the Japanese Islands to the northern Pacific, and (2) a zonally oriented course along $45^{\circ}-55^{\circ} \mathrm{N}$. On the other hand, cyclone tracks in 2000 show meridional diversity near the Japanese Islands. Some cyclones originated in southeast China or the East China Sea and traveled eastward and northward via the Korean Peninsula, Sea of Japan, and the Japanese Islands. This route reflects the preferred meteorological conditions for the transport of continentalAsian air masses to Japan. Consequently, meridional displacement or diversity of cyclone tracks may have caused low (high) $\mathrm{O}_{3}$ over WCJ in 1998 (2000). Similar features in MSLP fields and cyclone tracks were also found in 1983 (El Niño) and 1985 and 1996 (La Niña, not shown). In these years, the relationships among MSLP over the Pacific, continental-Asian outflow, and $\mathrm{O}_{3}$ concentrations seem to be consistent with the processes controlling springtime $\mathrm{BL}$ $\mathrm{O}_{3}$ over WCJ as described in Sects. 3.4 and 3.5. Note that Koumoutsaris et al. (2008) found significant increases in $\mathrm{O}_{3}$ exported from Asia to the western Pacific, including Japan, in March 1998 (El Niño). We examined the results for the same period simulated by $\mathrm{E}_{00} \mathrm{M}_{y y}$ and found that similar positive $\mathrm{O}_{3}$ anomalies appeared over the western Pacific. In 

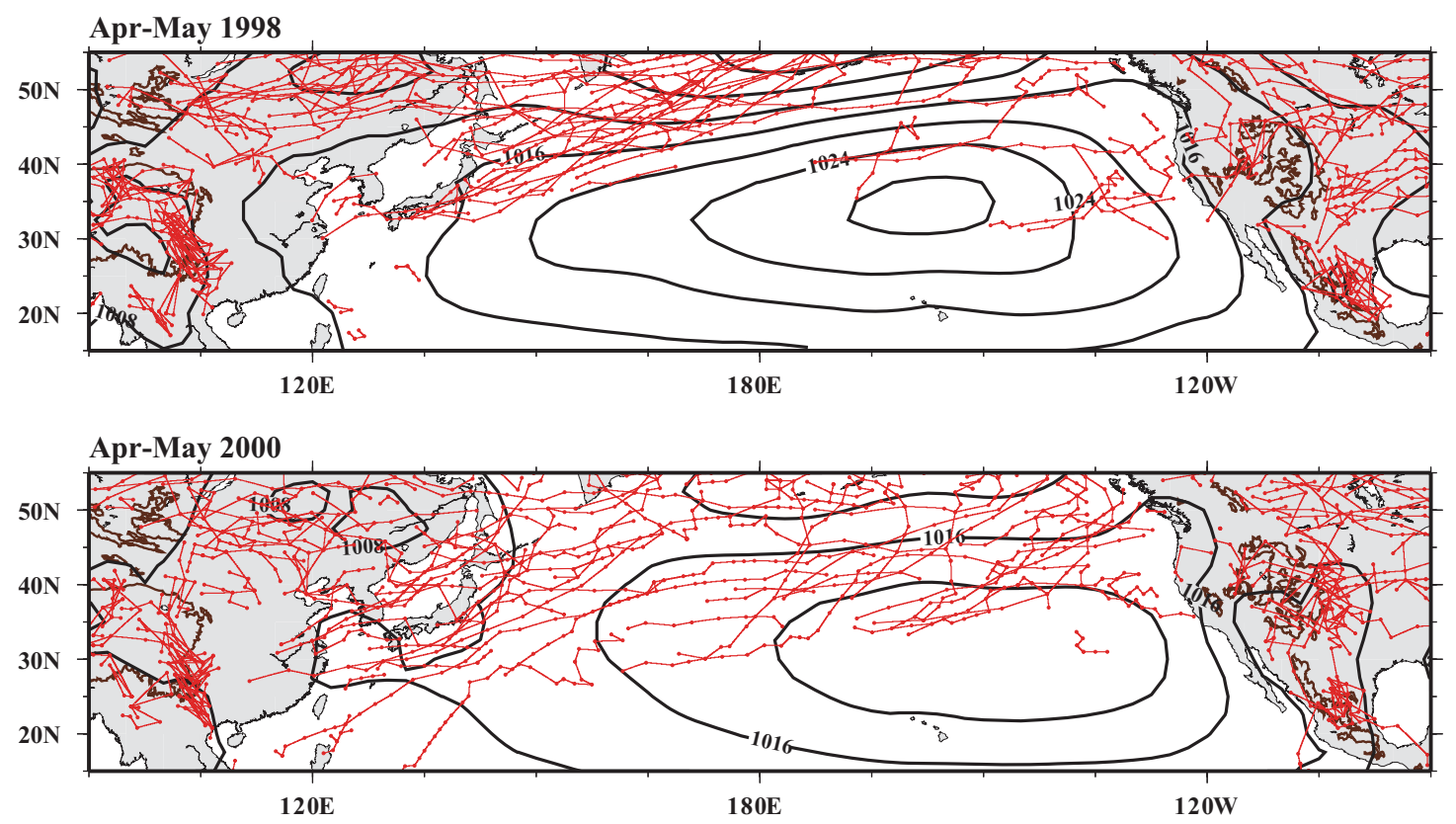

Fig. 11. Spatial distributions of mean sea level pressure overlaid with cyclone tracks during April and May 1998 (top, El Niño) and 2000 (bottom, La Niña).

our results, $\mathrm{O}_{3}$ anomalies over the central part of Japan were also positive, although those over the western part were negative. However, the positive $\mathrm{O}_{3}$ anomalies over the western Pacific in our model domain almost disappeared in April and May. Thus, the influences of El Niño in 1998 on $\mathrm{BL} \mathrm{O}_{3}$ over Japan might have differed between March and the subsequent springtime months of April and May.

The above findings suggest that it is probable that the meteorological variability caused by ENSO events is one of the important factors affecting the IAV of springtime $\mathrm{BL} \mathrm{O}_{3}$ over WCJ. However, the timing, period, and intensity of El Niño and La Niña are uncertain; thus, their influences are expected to be complicated. For example, a large $\mathrm{O}_{3}$ anomaly region in 1987 (an El Niño year) was slightly shifted compared with the composite field of low $\mathrm{O}_{3}$ over WCJ years, and ASPA was relatively small in 1989 (a La Niña year). In 1992, despite being an El Niño year, MSLP over the whole Pacific region was exceptionally low; thus, ASPA had a large negative value. The reasons for these discrepancies are not clear, and further studies are needed to understand the relations between ENSO and the IAV of $\mathrm{O}_{3}$ over WCJ.

\section{Conclusions}

We investigated the effects of meteorological variability on the interannual variation (IAV) of springtime $\mathrm{BL} \mathrm{O}_{3}$ over Japan. We conducted multiyear springtime simulations during 1981-2005 using the regional scale chemical transport model, CMAQ, and emission inventories, REAS. We performed two sets of numerical experiments. Simulation
$\mathrm{E}_{y y} \mathrm{M}_{y y}$ used the emission data sets and meteorological fields for each year. Another simulation, $\mathrm{E}_{00} \mathrm{M}_{y y}$, used the fixed emissions for 2000 and meteorological fields for each year. We evaluated the model reproducibility of the observed IAV of $\mathrm{O}_{3}$ over western and central Japan (WCJ) with the simulated results of $\mathrm{E}_{y y} \mathrm{M}_{y y}$. Then, we analyzed the influences of the IAV of meteorology on springtime $\mathrm{BL} \mathrm{O}_{3}$ over WCJ using the simulated results of $\mathrm{E}_{00} \mathrm{M}_{y y}$. We also examined the relationship between ENSO events and the IAV of $\mathrm{O}_{3}$ over WCJ.

The main results are summarized as follows:

1. The model simulation reproduced well both the shortterm variability and the long-term trend of the observed springtime surface $\mathrm{O}_{3}$ over WCJ. Year-to-year variations were larger than the annual rate of increase of the long-term trend. The IAV patterns of $\mathrm{O}_{3}$ anomalies over WCJ in the simulated results of $\mathrm{E}_{y y} \mathrm{M}_{y y}$ and $\mathrm{E}_{00} \mathrm{M}_{y y}$ were clearly similar, suggesting that the IAV of springtime $\mathrm{BL} \mathrm{O}_{3}$ over WCJ is mainly determined by the meteorological variability.

2. The composite $\mathrm{O}_{3}$ field for the high $\mathrm{O}_{3}$ over WCJ years showed that a high $\mathrm{O}_{3}$ area over CEC, the Korean peninsula, and Japan was slightly larger and shifted southward compared with the 25-year-averaged field. On the other hand, the corresponding area for the low $\mathrm{O}_{3}$ over WCJ years was somewhat smaller and shifted northward. As a result, large $\mathrm{O}_{3}$ anomalies appeared over WCJ. 
3. Large negative (positive) surface pressure anomalies appeared over the Pacific Ocean east of Japan in the composite field of the high (low) $\mathrm{O}_{3}$ over WCJ years. The area-weighted surface pressure anomaly in the springtime over that region (ASPA) was calculated as a reference parameter. When the absolute value of ASPA was large, ASPA showed good correlation with the IAV of $\mathrm{O}_{3}$ over WCJ. The IAV of $\mathrm{O}_{3}$ over WCJ and $\mathrm{O}_{3}$ flux anomalies along the western and southern boundaries of WCJ also showed good correlation.

4. The processes controlling the IAV of springtime $\mathrm{BL} \mathrm{O}_{3}$ over WCJ can be basically explained as follows. When ASPA has a large negative value, polluted air masses from continental Asia tend to be transported directly to WCJ by the strong westerly component of the wind field. In addition, the inflow of the clean maritime air masses from the Pacific Ocean to WCJ is small because southerly winds are weak. When ASPA has a large positive value, the influence of the continentalAsian outflow tends to be small because the westerly component of the wind fields around WCJ is relatively weak. In contrast, southerly winds around WCJ are relatively strong and transport clean air masses from the Pacific Ocean to WCJ. Consequently, springtime $\mathrm{BL} \mathrm{O}_{3}$ over WCJ is higher (lower) than in ordinary years when ASPA has a large negative (positive) value. In general, the IAV of $\mathrm{O}_{3}$ over WCJ is sensitive to the continentalAsian outflow. The influence of chemical process on the $\mathrm{IAV}$ of $\mathrm{O}_{3}$ over WCJ seems to be small.

5. Springtime $\mathrm{BL} \mathrm{O}_{3}$ over WCJ and ENSO events show some correlation and suggest that high and low $\mathrm{O}_{3}$ over WCJ years are respectively related to La Niña and El Niño. A massive anticyclone centered in the eastern Pacific appeared in 1998 (El Niño), whereas the maximum MSLP in 2000 (La Niña) was remarkably weak. Meridional displacement or diversity of cyclone tracks near Japan might have influenced the conditions for the transport of continental-Asian air and caused low (high) $\mathrm{O}_{3}$ over WCJ in 1998 (2000). Our findings suggest that the meteorological variability caused by ENSO events is one of the important factors affecting the IAV of springtime $\mathrm{BL} \mathrm{O}_{3}$ over WCJ. However, the relation between ENSO and the IAV of $\mathrm{O}_{3}$ over Japan is complicated and further study is required.

Acknowledgements. This work was supported by the Global Environment Research Fund of the Ministry of the Environment, Japan (C-81). We would like to acknowledge the entire staff of the EANET, the WDCGG, and the air quality monitoring stations of the Ministry of the Environmental of Japan and of local governments for carrying out measurements and providing observation data sets. We would like to thank K. S. Lam of the Hong Kong Polytechnic University for observation data at Hok Tsui station.
We are also thankful to H. Mukai of NIES for valuable comments. The GFD-DENNOU library, GTOOL, and Generic Mapping Tools (GMT, Wessel and Smith, 1998) were used for drawing the figures.

Edited by: O. Cooper

\section{References}

Akimoto, H.: Global air quality and pollution, Science, 302, 17161719, 2003.

Binkowski, F. S. and Shankar, U.: The Regional Particulate Matter Model 1, Model description and preliminary results, J. Geophys. Res., 100(D12), 26191-26209, 1995.

Byun, D. W. and Schere, K. L.: Review of the governing equations, computational algorithms, and other components of the Models3 Community Multiscale Air Quality (CMAQ) modeling system, Appl. Mech. Rev., 59, 51-77, 2006.

Carter, W. P. L.: Documentation of the SAPRAC-99 chemical mechanism for VOC reactivity assessment, final report to California Air Resource Board, Contract 92-329 and 95-308, California Air Resource Board, Sacramento, 2000.

Chou, C. C.-K., Liu, S. C., Lin, C.-Y., Shiu, C.-J., and Chang, K.H.: The trend of surface ozone in Taipei, Taiwan, and its causes: Implications for ozone control strategies, Atmos. Environ., 40, 3898-3908, 2006.

Doherty, R. M., Stevenson, D. S., Johnson, C. E., Collins, W. J., and Sanderson, M. G.: Tropospheric ozone and El Niño-Southern Oscillation: Influence of atmospheric dynamics, biomass burning emissions, and future climate change, J. Geophys. Res., 111, D19304, doi:10.1029/2005JD006849, 2006.

Guenther, A., Hewitt, C. N., Erickson, D., Fall, R., Geron, C., Graedel, T., Harley, P., Klinger, L., Lerdau, M., McKay, W. A., Pierce, T., Scholes, B., Steinbrecher, R., Tallamraju, R., Taylor, J., and Zimmerman, P.: A global model of natural volatile organic compound emissions, J. Geophys. Res., 100(D5), 88738892, 1995.

He, Y. J., Uno, I., Wang, Z. F., Pochanart, P., Li, J., and Akimoto, H.: Significant impact of the East Asia monsoon on ozone seasonal behavior in the boundary layer of Eastern China and the west Pacific region, Atmos. Chem. Phys., 8, 7543-7555, 2008, http://www.atmos-chem-phys.net/8/7543/2008/.

Intergovernmental Panel on Climate Change: Climate Change 2007: The Physical Science Basis: Contribution of Working Group I to the Fourth Assessment Report of the Intergovernmental Panel on Climate Change, edited by: Solomon, S., Qin, D. Manning, M. et al., Cambridge Univ. Press, New York, 2007.

International Energy Agency: Energy Balances of OECD Countries and Energy Balances of Non-OECD Countries (CD-ROM), Paris, 2006.

Kalnay, E., Kanamitsu, M., Kistler, R., Collins, W., Deaven, D., Gandin, L., Iredell, M., Saha, S., White, G., Woollen, J., Zhu, Y., Leetmaa, A., Reynolds, R., Chelliah, M., Ebisuzaki, W., Higgins, W., Janowiak, J., Mo, K. C., Ropelewski, C., Wang, J., Jenne, R., and Joseph, D.: The NCEP/NCAR 40-year reanalysis project, B. Am. Meteorol. Soc., 77, 437-471, 1996.

Kim, J. H., Lee, H. J., and Lee, S. H.: The characteristics of tropospheric ozone seasonality observed from ozone soundings at Pohang, Korea, Environ. Monit. Assess., 118, 1-12, 2006. 
Kistler, R., Kalnay, E., Collins, W., Saha, S., White, G., Woollen, J., Chelliah, M., Ebisuzaki, W., Kanamitsu, M., Kousky, V., van den Dool, H., Jenne, R., and Fiorino, M.: The NCEP-NCAR 50year reanalysis: Monthly means CD-ROM and documentation, B. Am. Meteorol. Soc., 82, 247-267, 2001.

Koumoutsaris, S., Bey, I., Generoso, S., and Thouret, V.: Influence of El Niño-Southern Oscillation on the interannual variability of tropospheric ozone in the northern midlatitudes, J. Geophys. Res., 113, D19301, doi:10.1029/2007JD009753, 2008.

Li, J., Wang, Z., Akimoto, H., Gao, C., Pochanart, P., and Wang, X.: Modeling study of ozone seasonal cycle in lower troposphere over east Asia, J. Geophys. Res., 112, D22S25, doi:10.1029/2006JD008209, 2007.

Lin, M., Holloway, T., Oki, T., Streets, D. G., and Richter, A.: Multi-scale model analysis of boundary layer ozone over East Asia, Atmos. Chem. Phys., 9, 3277-3301, 2009, http://www.atmos-chem-phys.net/9/3277/2009/.

Liu, H., Jacob, D. J., Bey, I., Yantosca, R. M., Duncan, B. N., and Sachse, G. W.: Transport pathways for Asian pollution outflow over the Pacific: Interannual and seasonal variations, J. Geophys. Res., 108(D20), 8786, doi:10.1029/2002JD003102, 2003.

Liu, J., Mauzerall, D. L., and Horowitz, L. W.: Analysis of seasonal and interannual variability in transpacific transport, J. Geophys. Res., 110, D04302, doi:10.1029/2004JD005207, 2005.

Maeda, J., Liang, C., Bandow, H., Maeda, Y., and Mizoguchi, T.: Response of KI oxidant analyzer for peroxyacetyl nitrate, J. Jpn. Soc. Atmos. Environ., 32, 425-430, 1997.

Mauzerall, D. L., Sultan, B., Kim, N., and Bradford, D. F.: $\mathrm{NO}_{\mathrm{x}}$ emissions from large point sources: variability in ozone production, resulting health damages and economic costs, Atmos. Environ., 39, 2851-2866, 2005.

Ministry of the Environment of Japan: The Continuous Monitoring Manual for Ambient Air, 5th edition: http://www.env.go.jp/air/ osen/manual_5th/index.html, last access: 27 August 2009, 2007.

Mukai, H., Hashimoto, S., and Tanimoto, H.: Standards for ozone and green house gases monitoring in Japan, Proceedings of the 48th Annual Meeting of Japan Society for Atmospheric Environment, 208-211, 2007.

Naja, M. and Akimoto, H.: Contribution of regional pollution and long-range transport to the Asia-Pacific region: Analysis of long-term ozonesonde data over Japan, J. Geophys. Res., 109, D21306, doi:10.1029/2004JD004687, 2004.

Nenes, A., Pandis, S. N., and Pilinis, C.: ISORROPIA: A new thermodynamic equilibrium model for multiphase multicomponent inorganic aerosols, Aquat. Geochem., 4, 123-152, 1998.

Ohara, T., Akimoto, H., Kurokawa, J., Horii, N., Yamaji, K., Yan, X., and Hayasaka, T.: An Asian emission inventory of anthropogenic emission sources for the period 1980-2020, Atmos. Chem. Phys., 7, 4419-4444, 2007,

http://www.atmos-chem-phys.net/7/4419/2007/.

Ohara, T., Yamaji, K., Uno, I., Tanimoto, H., Sugata, S., Nagashima, T., Kurokawa, J., Horii, N., and Akimoto, H.: Longterm simulations of surface ozone in East Asia during 19802020 with CMAQ and REAS, edited by: Borrego, C. and Miranda, A. I., NATO Science for peace and security series - C: Environmental Security, Air Pollution Modeling and its Application XIX, ISBN:978-1-4020-8452-2, Springer, 136-144, 2008.

Onogi, K., Tsutsui, J., Koide, H., Sakamoto, M., Kobayashi, S., Hatushika, H., Matsumoto, T., Yamazaki, N., Kamahori, H., Taka- hashi, K., Kadokura, S., Wada, K., Kato, K., Oyama, R., Ose, T., Mannoji, N., and Taira, R.: The JRA-25 Reanalysis, J. Meteorol. Soc. Japan, 85, 369-432, 2007.

Ordóñez, C., Brunner, D., Staehelin, J., Hadjinicolaou, P., Pyle, J. A., Jonas, M., Wernli, H., and Prévôt, A. S. H.: Strong influence of lowermost stratospheric ozone on lower tropospheric background ozone changes over Europe, Geophys. Res. Lett., 34, L07805, doi:10.1029/2006GL029113, 2007.

Pielke, R. A., Cotton, W. R., Walko, R. L., Tremback, C. J., Lyons, W. A., Grasso, L. D., Nicholls, M. E., Moran, M. D., Wesley, D. A., Lee, T. J., and Copeland, J. H.: A comprehensive meteorological modeling system - RAMS, Meteorol. Atmos. Phys., 49, 69-91, 1992.

Pochanart, P., Hirokawa, J., Kajii, Y., Akimoto, H., and Nakao, M.: Influence of regional-scale anthropogenic activity in northeast Asia on seasonal variations of surface ozone and carbon monoxide observed at Oki, Japan, J. Geophys. Res., 104(D3), 36213631, 1999.

Sadanaga, Y., Shibata, S., Hamana, M., Takenaka, N., and Bandow, H.: Weekday/weekend difference of ozone and its precursors in urban areas of Japan, focusing on nitrogen oxides and hydrocarbons, Atmos. Environ., 42, 4708-4723, 2008.

Schell, B., Ackermann, I. J., Hass, H., Binkowski, F. S., and Ebel, A.: Modeling the formation of secondary organic aerosol within a comprehensive air quality model system, J. Geophys. Res., 106(D22), 28275-28293, 2001.

Serreze, M. C.: Climatological aspects of cyclone development and decay in the Arctic, Atmos. Ocean, 33, 1-23, 1995.

Serreze, M. C., Carse, F., and Barry, R. G.: Icelandic low cyclone activity: Climatological features, linkages with the NAO, and relationships with recent changes in the northern hemisphere circulation, J. Climate, 10(3), 453-464, 1997.

Streets, D. G., Bond, T. C., Carmichael, G. R., Fernandes, S. D., Fu, Q., He, D., Klimont, Z., Nelson, S. M., Tsai, N. Y., Wang, M. Q., Woo, J.-H., and Yarber, K. F.: An inventory of gaseous and primary aerosol emission in Asia in the year 2000, J. Geophys. Res., 108(D21), 8809, doi:10.1029/2002JD003093, 2003.

Sudo, K., Takahashi, M., Kurokawa, J., and Akimoto, H.: CHASER: A global chemical model of the troposphere: 1. Model description, J. Geophys. Res., 107(D17), 4339, doi:10.1029/2001JD001113, 2002.

Tanimoto, H.: Increase in springtime tropospheric ozone at a mountainous site in Japan for the period 1998-2006, Atmos. Environ., 43, 1358-1363, 2009.

Tanimoto, H., Sawa, Y., Matsueda, H., Uno, I., Ohara, T., Yamaji, K., Kurokawa, J., and Yonemura, S.: Significant latitudinal gradient in the surface ozone spring maximum over East Asia, Geophys. Res. Lett., 32, L21805, doi:10.1029/2005GL023514, 2005.

Tanimoto, H., Mukai, H., Hashimoto, S., and Norris, J. E.: Intercomparison of ultraviolet photometry and gas-phase titration techniques for ozone reference standards at ambient levels, J. Geophys. Res., 111, D16313, doi:10.1029/2005JD006983, 2006.

Tanimoto, H., Matsumoto, K., and Uematsu, M.: Ozone-CO correlations in Siberian wildfire plumes observed at Rishiri Island, SOLA, 4, 65-68, doi:10.2151/sola.2008-017, 2008.

Terao, Y., Logan, J. A., Douglass, A. R., and Stolarski, R. S.: Contribution of stratospheric ozone to the interannual variability of tropospheric ozone in the northern extratropics, J. Geophys. Res., 113, D18309, doi:10.1029/2008JD009854, 2008. 
6304 J. Kurokawa et al.: Meteorological variability on interannual variations of springtime boundary layer ozone over Japan

United Nations: Statistical Yearbook, issue 49, New York, 2005.

United Nations: Statistical Yearbook, issue 50, New York, 2006.

Uno, I., Carmichael, G. R., Streets, D. G., Tang, Y., Yienger, J. J., Satake, S., Wang, Z., Woo, J.-H., Guttikunda, S., Uematsu, M., Matsumoto, K., Tanimoto, H., Yoshioka, K., and Iida, T.: Regional chemical weather forecasting system CFORS: Model descriptions and analysis of surface observations at Japanese island stations during the ACE-Asia experiment, J. Geophys. Res., 108(D23), 8668, doi:10.1029/2002JD002845, 2003.

Uno, I., Ohara, T., Sugata, S., Kurokawa, J., Furuhashi, N., Yamaji, K., Tanimoto, N., Yumimoto, K., and Uematsu, M.: Development of the RAMS/CMAQ Asian Scale Chemical Transport Modeling System, J. Jpn. Soc. Atmos. Environ., 40, 148-164, 2005.

Wang, X. and Mauzerall, D. L.: Characterizing distributions of surface ozone and its impact on grain production in China, Japan and South Korea: 1990 and 2020, Atmos. Environ., 38, 43834402, 2004.

Wessel, P. and Smith, W. H. F.: New, improved version of generic mapping tools released, EOS Trans. Amer. Geophys. Union, 79(47), 579, 1998.
Yamaji, K., Ohara, T., Uno, I., Tanimoto, H., Kurokawa, J., and Akimoto, H.: Analysis of the seasonal variation of ozone in the boundary layer in East Asia using the Community Multiscale Air Quality model: What controls surface ozone levels over Japan?, Atmos. Environ., 40, 1856-1868, 2006.

Yamaji, K., Ohara, T., Uno, I., Kurokawa, J., Pochanart, P., and Akimoto, H.: Future prediction of surface ozone over east Asia using Models-3 Community Multiscale Air Quality Modeling System and Regional Emission Inventory in Asia, J. Geophys. Res., 113, D08306, doi:10.1029/2007JD008663, 2008.

Yoshida, Y., Yumimoto, K., and Uno, I.: Evaluation of meteorological parameters over East Asia simulated by the Regional Meteorological Model, RAMS, J. Jpn. Soc. Atmos. Environ., 41, 235-248, 2006.

Zhang, M. G., Xu, Y., Uno, I., and Akimoto, H.: A numerical study of tropospheric ozone in the springtime in East Asia, Adv. Atmos. Sci., 21(2), 163-170, 2004. 